\title{
Violence and the Politics of Everyday Life
}

On Tuesday 17 March 1705 a notary from Bologna's Tribunale del Torrone visited Maddalena Faesini at her sickbed in the Ospedale di Santa Maria della Vita to interrogate her about the life-threatening wounds to her face that brought her there. ${ }^{1}$ She stated that she had received many blows to the head and jaw with an unidentified blunt object from a woman called Domenica Gombi. They knew each other and lived in the same street, and Maddalena suggested having been beaten up so badly because Domenica believed she had badmouthed her to the merchant they both worked for, presumably as spinners or weavers. The investigation of this injury, which had not only slashed the skin on Maddalena's face but also caused her teeth to fall out, was halted when the two made peace roughly two weeks later.

The casebooks of Bologna's criminal court's notaries are filled with violent altercations similar to this incident. Though discordant with normative expectations of women, these aggressions were an integral part of the day-to-day lives of male and female artisans, peddlers and labourers in Bologna's dense urban fabric. These violent altercations were also considered an unwelcome interaction worth denouncing to the court. This chapter explores the gendered dynamics of these quotidian violent behaviours recounted in the Tribunale del Torrone's denunciations and processi between the middle of the seventeenth and eighteenth centuries. Through the examination of these criminal court records, this chapter will draw attention to the distinguishing features of early modern Italy's culture of violence and, importantly, establish women's place in it. It will ultimately argue that women's violent behaviour was far too common to be viewed as an anomaly.

To this end, this chapter will first discuss the particular place of Italy, as a representative of the 'southern pattern,' in European comparisons of longterm patterns of violence. It will deal with how violence was regarded in the eyes of the law and how it was dealt with in practice, as the culture of violence went hand in hand with that of reconciliation throughout the early modern period. The next sections scrutinise women's participation in homicide as well as verbal aggression and, importantly, a wide range of non-fatal physical acts of violence. This chapter builds on recent scholarship that includes the pettier forms of violence in its analysis, which were far more common than their

1 АSво, Torrone, $7602-2$, fasc. 19. 
lethal counterparts, and are therefore more telling of men's and women's everyday encounters with violence and the law. The last sections will inquire about the gendered nature of this everyday violence through several important aspects: the use of weapons, the social profiles of and relations between offenders and victims, the spatial contexts in which violence took place as well as some recurring narrative frameworks regarding the violence of men and women in the judicial sources.

\section{$\mathbf{1}$ \\ The Culture of Violence between Prosecution and Reconciliation}

At least until the seventeenth century, violence was considered to be a regular feature of everyday life among many Western societies. ${ }^{2}$ Robert Muchembled went so far as to state that "like death, like the cemetery which is at the heart of the village, violence is at the heart of life in the fifteenth, sixteenth, and seventeenth centuries." ${ }^{3}$ A special place in the discussions about the role of violence in everyday life in the early modern period is held by the South of Europe, with the Italian peninsula as its main representative. Based on his work on sixteenth-century Rome, Peter Blastenbrei explicitly spoke of distinct Northern and southern European models of delinquency, in which the South distinguished itself by exhibiting much higher shares of violence. ${ }^{4}$ The equation of Italy with the South has not remained uncriticised. Scholars have, for example, called the cultural homogeneity of the region into question, and furthermore suggest that there are too few comparable quantitative analyses for most parts of this area to substantiate any such claim. ${ }^{5}$ Yet, a cautious eye on the available international literature seems pertinent to understand specificities and commonalities in societies' attitudes towards violence across early modern Europe.

Italy has been described as particularly violent compared to other early modern European societies. ${ }^{6}$ The special position of Italy in the long-term development of violence is furthermore highlighted in Manuel Eisner's

2 Davies, 'Introduction,' 1.

3 R. Muchembled, 'Anthropologie de la violence dans la France moderne (xve-XviIIe siècle),' Revue de synthèse 108 (1987) 40, as translated by Davies, 'Introduction,' 1.

4 Blastenbrei, Kriminalität in Rom, 283-284.

5 The equation of Italy with the south or the Mediterranean has also been subject to substantial criticism. Not only have scholars called the cultural homogeneity of the region into question, but there are also few comparable quantitative analyses for most parts of this area to substantiate any such claim. See Mantecón, 'The patterns of violence,' 243; Eisner, 'From swords to words,' $84-85$.

6 Carroll, 'Revenge and reconciliation,' 101-142 106-107; Calzolari, 'Delitti e castighi,' 55; Niccoli, 'Rinuncia, pace, perdono,' 188. 
integrative survey of European homicide rates. ${ }^{7}$ In England and Holland a sustained decline of lethal violence set in during the sixteenth century, followed soon after by Scandinavia, Germany and Switzerland during the first decades after 1600 , but the homicide rates in Italian cities remained high until well in the nineteenth century, only after this time declining steeply. As we will see in the next section, evidence from seventeenth- and eighteenth-century Bologna nuances this image, but does not contradict the broad outlines of the theory.

Why Italy remained so violent throughout the early modern period has been subject to much contemplation, but answers remain tentative. Scholars have often drawn on Norbert Elias' theory of the civilising process to explain the relatively quick decline in violence, including lethal violence, witnessed in northern Europe. ${ }^{8}$ The rise of greater self-control as individuals internalised social constraints was promoted by the expansion of the state, with its monopoly on violence, and the extension of the market economy. In a recent article Stuart Carroll aptly summarises why the case of Italy complicates this image. ${ }^{9}$ Already during the Italian Renaissance, social and economic interdependencies had reached levels far in advance of any in the North of Europe. Sophisticated bureaucratic and legal mechanisms had also been developed early on. In spite of these early administrative and judicial developments, the new regimes that emerged in Italy during the first half of the sixteenth century lacked the political legitimacy to effectively suppress the widespread factional violence at least until the middle of the seventeenth century. ${ }^{10}$

Scholars have also drawn on other cultural-institutional factors to explain the prevalence of violence in early modern Italy. Some have pointed to the persistence of an honour culture as a distinguishing feature of the Mediterranean region until well into the twentieth century. ${ }^{11}$ In an honour-based culture one's honour was measured and conferred by one's peers. Having a clear social function, violence was considered both legitimate and sometimes obligatory to assert, defend and win masculine honour and escape shame. ${ }^{12}$

Eisner, 'Long-term historical trends,' 83-142; M. Eisner, 'Modernization, self-control and lethal violence. The long-term dynamics of European homicide rates in theoretical perspective,' British journal of criminology 41 (2001) 618-638.

8 Its most notable supporter w Pieter Spierenburg. See, for example, Spierenburg, Violence and punishment; R. McMahon, J. Eibach and R. Roth, 'Making sense of violence? Reflections on the history of interpersonal violence in Europe,' Crime, history and societies 17:2 (2013) 7-11.

$9 \quad$ S. Carroll, 'Revenge and reconciliation in early modern Italy,' Past \& present 233 (2016) 105.

10 Ibidem, 106.

$11 \quad$ Eisner, 'Modernization, self-control and lethal violence,' 632; Carroll, 'Introduction,' 35; Davies, 'Introduction,' 1; Calzolari, 'Delitti e castighi,' 55.

Carroll, 'Introduction,' 23, 27; Wood, 'Conceptualizing cultures of violence,' 87. 
According to Carroll, a distinctive feature of early modern Italy was the widespread secular literature on the gentlemanly laws of honour and its relation to peacemaking. While the practice of peacemaking between individuals as a legitimate and honourable response to violence came under attack in northern Europe, it continued to be held in high esteem in Italy throughout the early modern period. ${ }^{13}$ The long continuity of peacemaking procedures in early modern Italy - notably also in a formal, judicial sense - and its role in preserving a social system based on violent confrontation has been treated more extensively earlier in this book.

Though some scholars have argued that it was comparably ineffective, premodern Italian states had since long attempted to contain violent behaviours. ${ }^{14}$ Indeed, medieval and early modern towns are considered to be the birthplace of measures of violence prevention and containment. ${ }^{15}$ On a regular basis, statutes, civil oaths and bans defined violent acts as deviant behaviour, a view that was supported by a range of arms bans and night curfews renewed throughout the early modern period. In early modern Bologna important sources that shed light on the authorities' stance towards violence are the Bando Generale of 1610 by cardinal legate Benedetto Giustiniani, and the one issued in 1756 by Fabrizio Serbelloni; summations of the criminal bylaws issued on the occasion of the new cardinal legate taking office. Although the prescribed sentences were not rigidly enforced, as we will see, they nevertheless reveal broader trends in the changing attitude towards deviant behaviours. ${ }^{16}$

While also delineating aggravating and extenuating factors, the seventeenth- and eighteenth-century criminal bylaws shared a pronounced disapproval of a wide range of violent behaviours and prescribed harsh sentences - even for instances where no blood was drawn (see table 10). According to Serbelloni's 1756 Bando Generale, homicide was considered to be one of the gravest crimes humans could commit. ${ }^{17}$ It was viewed as both contempt of the Papal Prince and as an offence against God. As a baseline all killers were

13 Carroll, 'Revenge and reconciliation,' 132.

14 F. Ricciardelli, 'Violence and repression in late medieval Italy,' in S.K. Cohn jr. and F. Ricciardelli (eds.), The culture of violence in Renaissance Italy (Florence: Le Lettere, 2012) 68; M.B. Becker, 'Changing patterns of violence and justice in fourteenth and fifteenth-century Florence,' Comparative studies in society and history 18:3 (1976) 282.

Dean, Crime and justice in late medieval Italy, 169; .G. Schwerhoff, 'Social control of violence, violence as social control: The case of early modern Germany,' in H. Roodenburg and P. Spierenburg (eds.), Social control in Europe. Volume I, 1500-1800 (Columbus: The Ohio State University Press, 2004) 235.

16 Angelozzi and Casanova, La giustizia criminale a Bologna nel XVIII secolo, 219-240.

17 'Fra li delitti, che nell'uman genere soglion commettersi, uno de' più gravi certamente è quello dell'omicidio volontario, che contiene in se una particolare offesa della Maesta 
TABLE 10 Sentences for violent acts prescribed by the criminal bylaws of 1610 and $175^{6}$

\begin{tabular}{|c|c|c|c|}
\hline Category & Condition & Punishments 1610 & Punishments 1756 \\
\hline Homicide & & Death penalty & Death penalty \\
\hline \multirow{7}{*}{$\begin{array}{l}\text { Wounding (ferite), } \\
\text { blows (percosse) or } \\
\text { threat }\end{array}$} & $\begin{array}{l}\text { Scarring to face/injury } \\
\text { of genitalia }\end{array}$ & $\begin{array}{l}\text { Fine of } 200 s c u d i+ \\
5 \text { years galleys }\end{array}$ & Life-long galleys \\
\hline & $\begin{array}{l}\text { Injury to other parts of } \\
\text { the body }\end{array}$ & $\begin{array}{l}\text { Fine of } 200 \text { scudi+ } \\
\text { strappado }\end{array}$ & - \\
\hline & Serious danger to life & - & Life-long galleys \\
\hline & Some danger to life & - & 7 years galleys \\
\hline & No danger to life & - & 5 years galleys \\
\hline & $\begin{array}{l}\text { With arms, no bodily } \\
\text { harm }\end{array}$ & $\begin{array}{l}\text { Fine of } 100 \text { scudi+ } \\
\text { strappado }\end{array}$ & Min. 5 years galleys \\
\hline & $\begin{array}{l}\text { With sticks, stones, } \\
\text { fists, pushes or kicks }\end{array}$ & Fine of 100 scudi & - \\
\hline Libels & - & $\begin{array}{l}\text { Death penalty }+ \\
\text { confiscation of goods }\end{array}$ & $\begin{array}{l}\text { Death penalty + } \\
\text { punishment of } \\
\text { 'degradation' }\end{array}$ \\
\hline Insult/banter & - & $\begin{array}{l}\text { Fine of } 50 \text { scudi }+ \\
\text { strappado }\end{array}$ & Strappado \\
\hline Spitting in face & - & $\begin{array}{l}\text { Fine of } 50 \text { scudi }+ \\
\text { strappado/1 month } \\
\text { imprisonment }\end{array}$ & $\begin{array}{l}\text { Strappado, in case } \\
\text { of noble/respect- } \\
\text { able victim galleys }\end{array}$ \\
\hline \multirow[t]{2}{*}{ House-scorning } & $\begin{array}{l}\text { Against citizens, } \\
\text { nobles or those of } \\
\text { 'honest condition' }\end{array}$ & Galleys for 5 years & Life-long galleys \\
\hline & $\begin{array}{l}\text { Against Persone vilio } \\
\text { meretrici }\end{array}$ & $\begin{array}{l}\text { Fine of } 200 \text { scudi }+ \\
\text { 'strappado' }\end{array}$ & $\begin{array}{l}\text { Life-long galleys, } \\
\text { subject to reduction }\end{array}$ \\
\hline $\begin{array}{l}\text { Violent kissing/ } \\
\text { touching of virgins or } \\
\text { other honest women }\end{array}$ & - & $\begin{array}{l}\text { Fine of } 300 \text { scudi }+ \\
\text { galleys for } 5 \text { years }\end{array}$ & - \\
\hline $\begin{array}{l}\text { Serenading widows, } \\
\text { single women or } \\
\text { other honest women }\end{array}$ & - & $\begin{array}{l}\text { Fine of } 100 \text { scudi+ } \\
\text { imprisonment for } \\
1 \text { month }\end{array}$ & Strappado \\
\hline
\end{tabular}

SOURCES: BANDO GENERALE (1610) 15-24; BANDO GENERALE (1756) 11-38, 108-110.

- Indicates that the category or criterion was not specifically addressed 
therefore prescribed a capital punishment in both bylaws. In Giustiniani's 1610 Bando Generale additional post-mortem corporal torture and disfigurements (supplizio) were stipulated for aggravating factors such as patricide.

One particularly gruesome capital punishment was imposed on Andrea Malagù on 15 July $1675 \cdot{ }^{18}$ Upon imprisonment for murder he had helped some other prisoners escape with a false key, but he had been caught and sent for trial. The printed announcement of his execution, which was intended as an invitation to the public, set out the grim procedure that awaited him: Andrea would be beaten to death, would have his throat slit and then quartered as a punishment for his crimes. Judging from the court records, elaborate spectacles like these were not that common during the seventeenth century and became increasingly rare as time went on. In the 1756 bylaws explicit mention of these additional defaming measures are notably absent, which is in line with the notion that punitive regimes during the early modern period moved away from the publicly visible infliction of pain and suffering as a symbol of the repressive potential of the state. ${ }^{19}$ Extenuating circumstances such as killing without malice and premeditation (resulting in five years in the galleys or forced labour) are treated more exhaustively in the eighteenth-century bylaws. Overall, the more elaborate treatment of these topics in the bylaws must be viewed foremost as the intent to clear up past ambiguities and systematise the application of criminal justice, and to diminish the discretion of the judges. ${ }^{20}$

There was a significant discrepancy between written laws and judicial practice. First, the penalty decreed by these bylaws would not necessarily be assumed in sentencing. As Gregory Hanlon has observed for the Renaissance period, statutory penalties were often deemed too harsh to apply. ${ }^{21}$ There were many aspects to a crime - such as the age, gender and social status of the offender and victim - that allowed the judge to apply judicial discretion and adjust the sentence. For this they did not only rely on the criminal bylaws, but also consulted the legal opinions by jurists such as Gian Domenico Rainaldi, who wrote several renowned books on legal topics based on his time as a judge in Bologna between 1671 and $1676 .{ }^{22}$ Second, many sentences in early modern Bologna were overturned and converted into pardons. This was especially true

divina, ed umana, un'atto di soprasina superbia contro Dio, ed il Principe, ed un'infinità d'altri mali." See Bando generale Serbelloni 1756, chapter vi, no. 1, page 11.

18 AsBo, Torrone, 7030, fasc. 9.

19 Eisner, 'From swords to words,' 103.

20 Angelozzi and Casanova, La giustizia criminale a Bologna nel XVIII secolo, 223.

$21 \quad$ Hanlon, 'Violence and its control,' 147.

22 See for an examination of his work Angelozzi and Casanova, La giustizia in una città di antico regime, 375-448; Casanova, Crimini nascosti. 
for acts of violence, where peacemaking between the offender and the victim or his/her family could result in a significant reduction of the sentence or a general pardon as the peace had restored the social equilibrium. In the case of homicides committed in seventeenth-century Bologna, nearly 40 per cent of the killers received a pardon. ${ }^{23}$ The granting of pardons and exemptions in response to a petition was not just an Italian phenomenon, but was widespread and is viewed as "fundamental to the manner of governing in early modern Europe."24

A third way in which penal practice diverged from the norms specifically relates to the treatment of various types of violence. Compared to the daily practice represented by the Torrone's denunciations and indictments, the heavy penalties prescribed for the pettier forms of violence are striking. For the wounding of another person without (in the eyes of the surgeon) any danger to life, the 1756 bylaws prescribe a sentence of five years rowing in the papal fleet. Insults and insulting banter could yield three pulls of the strappado. In practice, however, the Torrone only prosecuted the more serious forms of violence. As we can see in table 11, the notaries' record books brimmed with complaints about fights and brawls that did not result in life-threatening wounds. The criminal investigation dossiers on the other hand were disproportionally concerned with homicide and serious wounding.

The punishments that the bylaws prescribed also differed significantly from the ones that the criminal court pronounced in practice. As has already been observed by others, criminal court cases in early modern Bologna only rarely ended with 'real sentences,' such as the death penalty, a sentence to the galleys or exile. ${ }^{25}$ Homicide garnered a relatively large number of capital punishments, banishment sentences, and sentences of forced labour in the papal galleys compared to other types of violent crimes (table 12). A substantial proportion of killers were eventually pardoned, but they were less likely to be absolved from the get-go than was the case for other violent offenders. Cases against defendants in non-lethal violence cases were by and large cancelled, either due to insufficient evidence or, commonly, because the plaintiff withdrew the complaint due to an unmentioned settlement. Most of the non-lethal violence was concluded through peacemaking, despite the harsh sentences prescribed by the law.

The judicial treatment of women's violence differed from men's in some respects. From a theoretical viewpoint it is often believed that legal professionals

23 Rose, A renaissance of violence, 91.

24 Hanlon, 'Violence and its control,' 147.

25 Angelozzi and Casanova, Donne criminali, 228. 
TABLE 11 Violent crimes among denunciations and processi, ca. 1655-1755

\begin{tabular}{lcccccc}
\hline & Homicide & $\begin{array}{c}\text { Wounding } \\
\text { with danger } \\
\text { to life }\end{array}$ & $\begin{array}{c}\text { Wounding } \\
\text { without } \\
\text { danger to } \\
\text { life }\end{array}$ & $\begin{array}{c}\text { Verbal } \\
\text { aggression }\end{array}$ & $\begin{array}{c}\text { Undefined } \\
\text { violence }^{\mathrm{a}}\end{array}$ & Total \\
\hline $\begin{array}{l}\text { Denunciations } \\
(\mathrm{N}=1043)\end{array}$ & $1 \%$ & $7 \%$ & $56 \%$ & $22 \%$ & $14 \%$ & $100 \%$ \\
$\begin{array}{l}\text { Processi } \\
(\mathrm{N}=825)\end{array}$ & $20 \%$ & $45 \%$ & $20 \%$ & $15 \%$ & $1 \%$ & $100 \%$ \\
\hline
\end{tabular}

SOURCE: PROCESSI EXTRACTED FROM SAMPLE 1 AND 2B, DENUNCIATIONS FROM SAMPLE 2A (SEE APPENDIX), COUNTED BY IDENTIFIED DEFENDANT

a As measured by the issuing or breach of a precetto de non offendendo

TABLE 12 Sentences for violent crimes committed by men, ca. 1655-1755

\begin{tabular}{lcccccccc}
\hline & $\begin{array}{c}\text { Capital } \\
\text { punish- } \\
\text { ment }\end{array}$ & Exile & Galleys & $\begin{array}{c}\text { Incar- } \\
\text { ceration }\end{array}$ & Precetto $^{\text {a }}$ & Surety & Cancelled & Pardon \\
& & & & & & & \\
\hline Homicide (N=107) & $6 \%$ & $7 \%$ & $21 \%$ & $1 \%$ & - & $2 \%$ & $24 \%$ & $39 \%$ \\
$\begin{array}{l}\text { Wounding with danger } \\
\text { to life (N=205) }\end{array}$ & - & $2 \%$ & $3 \%$ & - & $9 \%$ & $1 \%$ & $75 \%$ & $10 \%$ \\
$\begin{array}{l}\text { Wounding without } \\
\text { danger to life (N=204) }\end{array}$ & - & $2 \%$ & $1 \%$ & - & $7 \%$ & $4 \%$ & $77 \%$ & $8 \%$ \\
$\begin{array}{l}\text { Verbal aggression (N=66) } \\
\text { Undefined violence }\end{array}$ & - & $2 \%$ & - & - & $14 \%$ & $9 \%$ & $71 \%$ & $5 \%$ \\
(N=86) & - & - & - & - & $100 \%$ & - & - & - \\
\hline
\end{tabular}

SOURCE: EXTRACTED FROM SAMPLE 1 AND SAMPLE 2 (SEE APPENDIX)

a Precetto de non offendendo

b Includes both cases that were absolved due to presumed innocence or lack of evidence as well as cancellations due to the complaint being withdrawn

treated female offenders with a particular leniency due to the assumption of their weakness and their need for protection (also called 'the chivalry theory'). ${ }^{26}$ Based on their extensive study of criminal justice in early modern Bologna, Angelozzi and Casanova concluded that the few women indicted for homicide

$26 \quad$ Ibidem, 18-19; Graziosi, 'Women and criminal law,' 173. 
Capital Exile Galleys Incar- Precetto $^{\mathrm{a}}$ Surety Cancelled ${ }^{\mathrm{b}}$ Pardon Total punish- ceration known ment

\begin{tabular}{|c|c|c|c|c|c|c|c|c|c|}
\hline Homicide $(\mathrm{N}=2)$ & - & - & - & $50 \%$ & $50 \%$ & - & - & - & $100 \%$ \\
\hline $\begin{array}{l}\text { Wounding with danger to } \\
\text { life }(\mathrm{N}=10)\end{array}$ & - & - & - & - & $30 \%$ & - & $70 \%$ & - & $100 \%$ \\
\hline $\begin{array}{l}\text { Wounding without danger } \\
\text { to life }(\mathrm{N}=54)\end{array}$ & - & - & - & - & $24 \%$ & $4 \%$ & $67 \%$ & $5 \%$ & $100 \%$ \\
\hline Verbal aggression $(\mathrm{N}=28)$ & - & - & - & - & $29 \%$ & $7 \%$ & $64 \%$ & & $100 \%$ \\
\hline Undefined violence $(\mathrm{N}=62)$ & - & - & - & - & $100 \%$ & - & - & & $100 \%$ \\
\hline
\end{tabular}

SOURCE: EXTRACTED FROM DENUNCIATIONS AND PROCESSI FROM SAMPLE 1 AND SAMPLE 2 (SEE APPENDIX)

a Precetto de non offendendo

b Includes both cases that were absolved due to presumed innocence or lack of evidence as well as cancellations due to the complaint being withdrawn

disproportionally received clemency, particularly when they had male co-offenders. In this case they were punished less severely or not at all. ${ }^{27}$ Rose similarly contended that the few women that came before the Torrone for homicide during the seventeenth century were treated as accomplices rather than as killers with agency. ${ }^{28}$

Acts of non-lethal violence were more common and allow for better examination of gendered sentencing patterns. What stands out is the importance of the precetto criminale, a conditional fine demanding the discontinuance of offending and molestations (see table 13). In proportional terms female offenders were on average at least twice as likely to receive such peace injunctions as their male counterparts, for all types of recorded violent transgressions. It is not unlikely that the women's legal minority played into the scale to which these measures were imposed on them. Not only did these injunctions serve to protect the victims (often other women) from further aggression, but they were likely also imposed to protect female offenders against themselves. Whether this meant that women's violence was largely irrelevant in the eyes

27 Angelozzi and Casanova, Donne criminali, 239, 242, 259. My own sample only includes four female offenders indicted for lethal violence. Two of them were sentenced: one was incarcerated and the other female offender received a precetto criminale.

28 Rose, $A$ renaissance of violence, 15 . 
of the court, or that they were actually subjected to close institutional scrutiny due to an intolerance of women's public violence, is still to be unravelled.

The criminal court records also reveal a decisive similarity in the judicial treatment of violence, regardless of gender. After all, the majority of cases against female fighters were also cancelled and absolved following the withdrawal of the complaint, just like men's. Cultural and judicial norms neither prevented women from employing violence, nor excluded them from employing the peacemaking practices that are believed to have been so intrinsic to the Italian culture of violence.

Although violence was viewed as undesirable, it also enjoyed a certain degree of tolerance. This was not only the case in Bologna and other Italian towns, but has also been observed for other regions during the early modern period. In Germany, for example, only notorious violent offenders faced severe sanctions like imprisonment or banishment, while non-lethal violent acts were commonly only punished with fines. ${ }^{29}$ Rather than punishment, the goal was to reconcile the two parties, to reintegrate the culprit into society and to re-establish social peace. Even though the Bolognese criminal bylaws officially prescribed harsh sentences, its court officials themselves are believed to have played active roles in pressuring the victims and their kin to accept their enemies' peacemaking. ${ }^{30}$

Expectations of peacemaking extended to all reaches of society, something which is illustrated by the case of Giacoma Ferranina against Pellegrina Gentili in $1655 \cdot{ }^{31}$ As Giacoma, a prostitute, was walking home with her mother and sister after mass, Pellegrina beat her with a stick and scarred her face. This was a serious offence, punishable by a hefty fine and a five-year sentence to the galleys. Offender Pellegrina understandably tried multiple times to have Giacoma renounce her complaint, which she refused. Pellegrina then turned to the court with a petition. She explained that she had previously been insulted and provoked by the plaintiff, which had led to the attack. She furthermore declared only having wounded Giacoma slightly, had many times (unsuccessfully) asked for a renunciation and was therefore now pleading for the case to be annulled by the judge without the renunciation. ${ }^{32}$ The petition was granted

\footnotetext{
29 Schwerhoff, 'Social control of violence,' 223, 235.

$30 \quad$ Rose, $A$ renaissance of violence, 54 .

$31 \quad$ Asbo, Torrone, 667o, fasc. 9 .

$32 \quad$ Ibidem, n.p, fol. 7: "Pellegrina Gentili humilmente espone all'curia esser stata querelata nel Torrone da donna Margherita Ferranina, et sua figliola meretrice perche essendo stata ingiuriata, et provocata dalle sud: le dasse con un bastone alcune percosse dalle quali restò pochissimo offesa, et havendogli l'querelatrice più volte fatto addimandargli la
} 
and the case was annulled against Giacoma's wishes. Clearly, reintegration was valued over punishment in cases such as these.

While the practice of peacemaking as a socially acceptable answer to acts of violence was shared within much of Europe, scholars have argued that it nevertheless may have been at the root of Italy's especially violent society. A scholar of the nineteenth century himself, Daniele Boschi stressed the decisive relationship between the persistent high rates of violence and the late modernisation of the criminal justice system in Italy. ${ }^{33}$ In particular, he points to the long-standing tradition of judicial indulgence towards interpersonal violence. Throughout the early modern period, he asserts, people accused of nonlethal violent crimes easily managed to avoid at least the most severe forms of punishments thanks to the complex system of judicial pardons and private reconciliations. And although criminal courts all over Italy received several thousand reports each year concerning a wide range of crimes, they effectively only dealt with a very small proportion of these offences. Therefore, until well into the nineteenth century the judicial system only exerted a very moderate deterrent power over violent aggressors. The question whether the practice of peacemaking and pardoning was more commonplace in Italy than elsewhere or whether it is more visible in the extant sources merits further investigation. However, what is certain is that peacemaking was of continued importance to the way interpersonal violence was dealt with all throughout the early modern period.

\section{Lethal Violence in the Seventeenth and Eighteenth Centuries}

In the scholarly debates on the decline of violence over time, homicide rates have formed the most important evidence to argue for the existence of regional differences. Eisner has been a main driver of the conceptualisation of these large-scale and long-term geographical variations. ${ }^{34} \mathrm{He}$ argued for a largely synchronised decline in violent crime across the Western world, where lethal encounters dropped from anywhere between 20 and 50 per 100,000 inhabitants in late medieval cities, to rates below one by the mid-twentieth century. ${ }^{35}$ England and the Netherlands led the way in this development during the sixteenth century, followed soon after by Scandinavia, Germany, Belgium,

renoncia sempre ha ricusato di fargliela, che perciò supp.ca l'curia a farle grazie d'ordinare che le sia cassata detta querella senza detta renoncia."

33 Boschi, 'Knife fighting in Rome,' 150-153, especially 152.

34 For his most recent account, see Eisner, 'From swords to words,' 65-134.

35 Ibidem, 67. 
Switzerland and France. Italy (representing the 'southern' pattern) pursued a different trajectory, with consistently higher rates than those in northern Europe followed by a gradual decline from the early nineteenth century onward. ${ }^{36} \mathrm{~A}$ simplified version of Eisner's data - which illustrates Italy's divergent trajectory - is presented in table 14 .

Despite the clear overall trend of higher mean homicide rates in Italy, a closer look at the data reveals significant variations between cities and time periods. ${ }^{37}$ For the premodern, pre-statistical era Eisner had to rely on discontinuous local estimates from various towns such as Rome, Florence, Venice, Siena, Mantua and Bologna. At least until the middle of the seventeenth century, high and low rates alternated without a distinguishable pattern. In fourteenth-century Florence, for example, the rate of 25.6 homicides per 100,000 inhabitants in 1344-1345 surged to a massive $15^{2}$ five years later (1350-1352), to drop to 16.4 again a quarter of a decade later (1374-1375). ${ }^{38}$ Similarly, local estimates for sixteenth-century Rome diverged from 73 in $1560-1562$ to 40 in $1571-1573 .{ }^{39} \mathrm{Be}-$ tween cities, too, significant variations arise. In the city of Mantua between 1601 and 1605 , the mean homicide rate was 31 . In Lecce during roughly the same time period (1601 to 1610 ), the rate was a lower 19.3. ${ }^{40}$ However, despite these variations even many of these lower estimates for Italian towns were higher than the mean rates for other parts of Europe throughout the early modern period.

The capriciousness of early modern homicide rates can also be observed in Bologna. Figure 7 displays these rates for the period between 1600 and 1755 collected from the criminal court's indictments. With an average of 27 homicides per 100,000 inhabitants throughout the century, it shows that - as a whole the Bolognese saw many killings. ${ }^{41}$ Compared to the average rates of the

$36 \quad$ Ibidem, 68,8 o- 81,84 .

37 I would like to express my gratitude to Manuel Eisner for kindly sending me his database (sent on 9 January 2014), in which he has collected and calculated the homicide rates for individual towns.

38 Based on Eisner's database, who gathered this data from A. Zorzi, 'La pena di morte in Italia nel Tardo Medioevo,' Clio \& Crimen 4 (2007) 47-62; A. Zorzi, 'Aspetti e problemi dell'amministrazione della giustizia penale nella repubblica fiorentina I. La transizione dal XIV al XV secolo,' Archivio storico italiano 145 (1987) 391-453.

39 Based on Eisner's database, who gathered this data from Blastenbrei, Kriminalität in Rom.

40 Based on Eisner's database, who gathered this data from M.A. Romani, 'Criminalità e giustizia nel Ducato di Mantova alla fine del cinquecento,' Rivista storica Italiana 92 (1980) 679-706; N. Perego, Homini de mala vita. Criminalità e giustizia a Lecco e in terra di Brianza tra cinque e seicento (Lecco: Oggiono, 2001) 196.

41 For fourteenth- and fifteenth-century Bologna, homicide rates ranged from 30 to 80 per 100,00o inhabitants. See T. Dean, 'Eight varieties of homicide. Bologna in the 1340s and 1440s,' in T. Dean and K. Lowe (eds.), Murder in Renaissance Italy (Cambridge: Cambridge 
TABLE 14 Mean homicide rates in European regions, 1350-1925

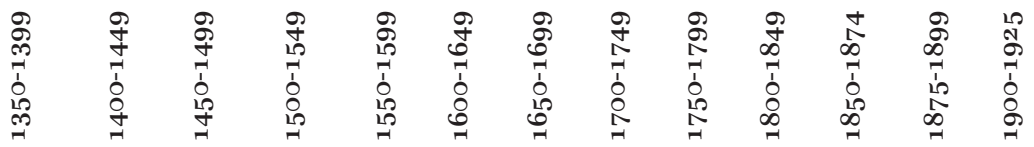

\begin{tabular}{|c|c|c|c|c|c|c|c|c|c|c|c|c|c|}
\hline England and Wales & 13.0 & $\ldots$ & $\ldots$ & $\ldots$ & 5.2 & 5.8 & $3 \cdot 5$ & 2.0 & 1.4 & 1.6 & 1.6 & 1.3 & 0.8 \\
\hline Netherlands & 20.7 & 59.1 & $\ldots$ & $35 \cdot 9$ & 8.9 & 7.6 & 3.1 & 3.4 & 1.9 & $\ldots$ & 0.8 & 0.9 & o.6 \\
\hline Germany & 30.1 & 6.6 & 18.6 & $\ldots$ & 9.0 & 10.1 & 3.1 & 5.0 & 4.6 & 2.4 & 1.5 & 1.6 & 2.1 \\
\hline Italy & 71.7 & 62.0 & $\ldots$ & $\ldots$ & $3^{8.7}$ & 39.1 & 10.2 & 16.9 & 7.1 & 8.0 & 7.0 & $5 \cdot 7$ & 3.9 \\
\hline
\end{tabular}

SOURCE: EISNER, 'FROM SWORDS TO WORDS', 80-81

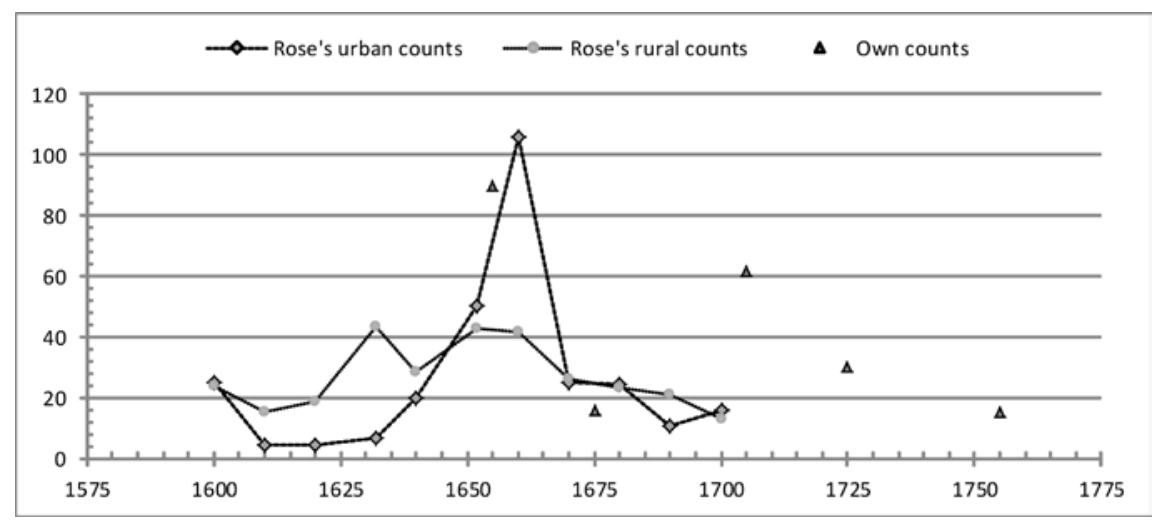

FIGURE 7 Bologna's urban homicide rates based on the processi, 1600-1755 SOURCES: SAMPLE 1 (SEE APPENDIX); C. ROSE, A RENAISSANCE OF VIOLENCE, 79-140. COUNTED AS HOMICIDES PER 100,000 INHABITANTS

Netherlands and England, Bologna's homicide rate of 25 at the beginning of the century was already quite high, but this was nothing compared to what was yet to come. In the decades after the outbreak of the bubonic plague in 1630, accompanied by a general dissolution of social order, the rates would surge to 50 in 1652 and to a staggering 106 homicides per 100,00o inhabitants in the city

University Press, 2017) 85; S. Rubin Blanshei, 'Homicide in a culture of hatred: Bologna 1352-1420,' in T. Dean and K. Lowe (eds.), Murder in Renaissance Italy (Cambridge: Cambridge University Press, 2017) 113. 
of Bologna in $166 \circ .{ }^{42} \mathrm{~A}$ decade later, however, the rates reached near parity again with those from the beginning of the century. With the high 1705 data point as an outlier, the post-1770 rates apparently continued the early modern routine, without a sensational deviation from the high rates associated with the 'southern pattern.'

Aside from the period of crisis between the 1630 s and 166 os, lethal violence in Bologna shared many of the same characteristics throughout the seventeenth and eighteenth centuries and resembled what is known about lethal violence in other early modern towns. They social realm of violent offenders will be treated more extensively in a later paragraph, but it is interesting to briefly point out its most important features. According to Rose, who provides an in-depth study of lethal violence in seventeenth-century Bologna, the Bolognese rarely killed strangers during times of peace. ${ }^{43}$ Instead, homicides took place within the orbit of family and sociability. Artisans, labourers and merchants killed each other, their families, their lovers, friends and neighbours. Their motivations were generally rather 'prosaic' or 'trivial', revolving around revenge for an insult, romance and escalated robbery as much in the 16oos as it did one and a half centuries later. In about a quarter of the cases killers fought alongside their family members, their co-workers or faction members, but much of the violence was a solitary affair. The violent encounters that led to the deaths recorded by the Torrone generally occurred in the course of daily conflict, a reality that early modern Italians were accustomed to and, indeed, embraced to a certain extent. ${ }^{44}$

As is known for lethal violence all over early modern Europe, the demographics of fatal violence in seventeenth- and eighteenth-century Bologna included few women. Men overwhelmingly accounted for the killers and their victims, which has led to the characterisation of homicide as "masculine bravado" revolving around "maintaining face, demonstrating character, not wanting to be pushed around, in short the requirement to defend one's (masculine) honour and reputation." ${ }^{25}$ Congruent with this dominant image of public male-on-male violence, women were much less frequently prosecuted for homicide and were also relatively uncommon among the reported victims of fatal interpersonal violence. Shares of female offenders in this category of violence range from 30 per cent in Surrey between 1660 and 1800 to about

\footnotetext{
42 Rose, A renaissance of violence, 137-138, 159.

43 Rose, A renaissance of violence, 91, 98, 103.

44 Ibidem, 91.

45 Carroll, 'Introduction,' 20.
} 
8 per cent in Amsterdam during the same time period. ${ }^{46}$ A similar, though amplified, image emerges for early modern Bologna. Rose calculated that women made up about 9 per cent of the victims of homicide and a mere 2.5 per cent of killers in seventeenth-century Bologna. ${ }^{47}$ For the period from 1583 to 1779 , Angelozzi and Casanova similarly allege that women made up less than five per cent of the indicted killers. ${ }^{48}$ My samples of urban Bologna between the midseventeenth and mid-eighteenth centuries concur with these assertions, and suggest that only three per cent of killers identified by the criminal court consisted of women. ${ }^{49}$

That women were only held accountable for a rather small proportion of homicides should not lead us to conclude that women were rarely violent at all. Recent studies have demonstrated that the examination of women's violence requires a different approach and a different set of sources than commonly employed. Rather than being dealt with by the higher courts, women's crimes were more likely to be handled by less formal methods of conflict resolution as well as in lower criminal courts. ${ }^{50}$ In recent decades, scholars have contended that focusing on petty violence - like petty criminality in general helps significantly in arriving at a clearer image of daily tensions in early modern communities as well as early modern men's and women's perceptions and experiences of violence." ${ }^{51}$ In Bologna too, the examination of a broader spectrum of violence beyond homicide bring a much more significant group of deviant female protagonists into view.

46 As offenders in lethal violence, women made up almost 30\% in Surrey (166o-180o) when including infanticide, and $13 \%$ of offenders of homicide and manslaughter alone. Women furthermore consisted of about $25 \%$ in Denbighshire (166o-1730), about one-fifth in seventeenth-century Cheshire, $21 \%$ in eighteenth-century Scotland and 8\% in Amsterdam between 1650 and 1810 . See J.M. Beattie, Crime and the courts in England, 1660-1800 (Princeton: Princeton University Press, 1986) 83, 115; Beattie, 'The criminality of women,' 85; S. Howard, 'Crime, communities and authority in early modern Wales: Denbighshire, 166o1730' (Unpublished PhD thesis, University of Wales, 2003) 83; Walker, Crime, gender and social order, 109; Kilday, Women and violent crime, 43; P. Spierenburg, 'How violent were women? Court cases in Amsterdam, 1650-1810,' Crime, history \& societies 1 (1997) 17.

47 Rose, A renaissance of violence, 148.

48 Angelozzi and Casanova, Donne criminali, 84.

49 My sample of the urban processi from 1655, 1675, 1705, 1725 and 1755 includes a total of 74 homicides resulting in 126 accused offenders. Four of these perpetrators were women.

50 Schwerhoff, Köln im Kreuzverhör; Shoemaker, Prosecution and punishment, 292; King, Crime and law in England, 202-210; Gray, Crime, prosecutions and social relations, 9, 170-171; Dinges, 'The uses of justice,' 159-175.

$51 \quad H u r l-E a m o n$, Gender and petty violence, 11; Jones, Gender and petty crime, 8; Walker, Crime, gender and social order, 270; Kilday, Women and violent crime; Ruitenbeek, 'Niet zonder kleerscheuren,' 62-85; Van der Heijden, 'Women, violence and urban justice,' 90. 
Compared to compelling accounts of murder, complaints about verbal affront may at first glance appear rather inconsequential. Yet early modern magistracies heard numerous insult cases on a daily basis, revealing in the very least a contemporary sensitivity to vilification that rendered it worthy of legal recourse. The desire to discipline interpersonal violence, whether physical or verbal, was intrinsically tied up with ideas about honour. Both words and physical actions were believed to have the power to wound the victim physically or through the loss of reputation, could provoke further violence, damaged wider family networks, and required reparation. ${ }^{52}$ The statutes that many Italian communities published from the Middle Ages onwards therefore treated hostile words and physical assaults in a similar manner. ${ }^{53}$ In Bologna the criminal bylaws discussed these types of 'injuries' in the same paragraphs and prescribed the same harsh punishments, while the judiciary in practice actively pushed for reconciliation. ${ }^{54}$

Italian women's roles in these acts of violence are still largely uncharted. As a result of the relatively strict gender norms and the ethics of honour it is assumed that women would not have partaken in the physical violence so very omnipresent in early modern Italy. Retributive violence was a culturally accepted and sometimes even demanded means to maintain one's honour - for men, but not for women. In his work on criminal justice in late Renaissance Florence, John Brackett has argued that for women it was neither 'expected nor desirable' to engage in violence for any reason. ${ }^{55}$ The ethics of honour prescribed passivity to women, submitting her to the control of men and relying on them to defend her honour and reputation.

Scholars have long assumed that women instead relied on insults and defamatory slurs as the primary means of conducting the small politics of their daily lives. ${ }^{56}$ Women, it is commonly argued, primarily assisted in violent

$5^{2} \quad$ Carroll, 'Introduction,' 23, 27.

53 References to statutes are mentioned in E. Horodowich, Language and statecraft in early modern Venice (Cambridge: Cambridge University Press, 2008) 93-96.

54 Chapter XLVII 'On injuries and insults': Bando generale della legazione di Bologna e suo contado, fatto pubblicare li 12. ottobre 1756 dall'eminentiss., e reverendiss. sig. cardinale Fabrizio Serbelloni, legato a latere di detta città, Bologna, 1756, 86-87.

Brackett, Criminal justice and crime in late Renaissance Florence, 133-134. Also see L. Martines, 'A way of looking at women in Renaissance Florence,' Journal of medieval and renaissance studies 1 (1974) 15-28.

56 S.T. Strocchia, 'Gender and the rites of honour in Italian Renaissance cities,' in J.C. Brown and R.C. Davis (eds.), Gender and society in Renaissance Italy (London: Longman, 1998) $52-54$. 
scenes with their voices and gestures. ${ }^{57}$ Scholars like Daniel Lesnick and Sharon Strocchia have argued that the ritualized vocabulary of vilification - aimed at influencing friends, neighbours or relatives in the community - was in fact a distinctly female form of crime that gave women of all social classes an informal but major means of influencing and shaping public opinion in a highly patriarchal society. 58 "The language of slander," Laura Gowing asserts based on her research into seventeenth-century London, "offered particular linguistic powers to women through which they asserted their verbal, physical, and legal agency to judge and condemn other women."59 As such, court records reveal the important roles of women in policing the social and sexual morality of their communities through gossip and insults. ${ }^{60}$

It would nevertheless be erroneous to characterize verbal affront as a 'typically female crime.' There is an increasing body of evidence that early modern European women did not limit themselves to verbal aggression. In seventeenth- and eighteenth-century Bologna, over four-fifths of the complaints made to the Torrone against female offenders concerned violence in its broadest sense of the word, but only one-fifth of these complaints spoke of verbal violence alone. ${ }^{61}$ The court dockets suggest that women physically fought their neighbours, acquaintances, economic competitors, their customers and their employers - and played considerably larger roles as defendants before the criminal court than normative prescriptions would ever suggest. Of course, the verbal assaults that were litigated in court only represent a small fraction of the conflicts arising at the most basic levels of everyday life. Many physical assaults also mention the exchange of injurious words, often setting in motion a chain of physical aggression around which the case would then centre. Clearly, however, early modern women did not solely rely on the sharpness of their tongues to settle their conflicts; an observation that is also confirmed by other recent studies on towns in Italy and elsewhere in Europe. ${ }^{62}$

$57 \quad$ Crouzet-Pavan, 'Crimine e giustizia' 57.

58 D.R. Lesnick, 'Insults and threats in medieval Todi,' Journal of medieval history 17 (1991) 76; Strocchia, 'Gender and the rites of honour,' 54;

59 Gowing, Domestic dangers, 109.

6o Ibidem, 101; Rublack, The crimes of women in early modern Germany, 220; S. Lipscomb, 'Crossing boundaries: Women's gossip, insults and violence in sixteenth-century France,' French history 25:4 (2011) 411.

61 Counted in the denunciations, where the judicial filter was arguably the smallest. Among the 241 female offenders in the denunciations collected, 46 were accused of insults, threats or other forms of verbal aggression.

62 Vasta, 'Per una topografia della violenza femminile,' 59-81; Angelozzi and Casanova, Donne criminali; Cohen, 'Honor and gender in the streets of early modern Rome,' 616, 623; S.K. Taylor, 'Women, honor, and violence in a Castilian town, 16oo-165o,' The sixteenth 
Moreover, defamatory speech was by no means a female preserve. A study of Venice's Avogaria di comun in the sixteenth and early seventeenth century revealed that the brunt of the state lawyers' rigour fell on the verbal aggression by and against men up the social ladder: on male members of the underclasses hurling insults at nobles or state officials, disrupting civic peace. ${ }^{63}$ Records from other councils such as Venice's Signori di notte, which primarily shouldered the responsibility to control verbal injuries in early modern Venice, could have perhaps balanced the scale, had these records survived the passing of time. ${ }^{64}$ The dissonant images of the social landscape of aggression that different court records paint, emphasize that a characterization of verbal injury as 'typically female' is too simplistic. In early modern Bologna, women constituted around one-fifth of the bolognesi accused of insults and threats between the mid-seventeenth and mid-eighteenth century. ${ }^{65}$ This does not deny that defamatory speech was a powerful tool for women to negotiate power in their everyday lives, but instead suggests that these mechanisms were not exclusive to them. In an honour-based culture, the power of insults to mar reputations rendered them useful currency for both men and women.

Verbal injury is often viewed in relation to morality. While the court records attest to women's ability and audacity in violently confronting their male and female adversaries for a wide range of motives, court testimonies reveal that it was nonetheless considered 'unladylike' comportment that was explicitly frowned upon by contemporaries. ${ }^{66}$ By acting aggressively, women disrupted order in a practical sense, as well as normatively by defying their prescribed gender roles. Morality was also important because of the lexicon of verbal affront, which for women often made allusions to her indecency. Peter Burke convincingly argued that insults can be viewed as breaches of social and cultural codes of conduct, but that they did follow cultural rules and conventions 'as closely as a sonnet.' ${ }^{67}$ Indeed, in early modern Italy the vocabulary of affront drew from a 'stereotyped, gender-loaded stockpile of invectives which both

century journal, 35:4 (2004), 1080; Lipscomb, 'Crossing boundaries,' 411; D. Roussel, 'La description des violences féminines dans les archives criminelles au Xvie siècle,' Tracés. Revue de Sciences humaines 19 (2010) 71; Hurl-Eamon, Gender and petty violence, 2005; Kilday, Women and violent crime in Enlightenment Scotland; Van der Heijden, Women and crime in early modern Holland.

63 Horodowich, Language and statecraft, 101.

64 Ibidem, 98 .

65 In my sample, 53 out of 26 o defendants accused of insults, defamation and threats were women.

66 Cohen, 'Honor and gender,' 133-134.

67 P. Burke, The historical anthropology of early modern Italy (Cambridge: Cambridge University Press, 1987) 96. 
women and men adapted according to the needs of the situation.' ${ }^{68}$ Defamatory speech therefore followed gendered conventions and value systems.

Research on towns all over medieval and early modern Europe has distinguished a basic division between the insults directed at women and those directed at men. ${ }^{69}$ Evidence both from secular and ecclesiastical courts suggests that the term of insult against women were often sexual in form. ${ }^{70}$ Research on medieval Todi and late-medieval Bologna suggest that insults to women were indeed overwhelmingly sexual, impugning her as some variant of a whore, adulteress or procuress. ${ }^{71}$ Slurs for women in early modern Bologna also regularly referred to their sexual honour and, as Angelozzi and Casanova remarked, often concerned a substantial subordination to the dominant masculine cultural model: puttana (whore), buzzerona (a woman dedicated to sodomite practices), sfondata (worn out), porca (sow), vacca (cow) and ruffiana (pimp) were the most common abuses used for women. ${ }^{72}$

A traditional understanding of these slanderous words is that they directly called into question the sexual reputation of their victim. Since a woman's moral value was bound up in her sexual status and role as a producer of legitimate heirs, defamers would consciously draw upon the specific, gendered meanings of words such as 'whore' or 'cuckold' to make their insults as effective as possible, exposing the private acts of their victims. ${ }^{73}$ More recently, however, scholars working on early modern England, Germany and Spain have argued that sexualized insult was only obliquely related to women's actual sexual behaviours. Sexualized insults actually represented concerns about a wide range of economic and social resources, such as financial extravagance or economic independence. ${ }^{74}$

Occasionally the slurs recorded in the Bolognese court records referred to the (surmised or imputed) sexual behaviours of the female recipients. In 1725

68 Strocchia, 'Gender and the rites of honour,' cit., p. 54.

69 D. Garrioch, 'Verbal insults in eighteenth-century Paris,' in P. Burke and R. Porter (eds.), The social history of language (Cambridge: Cambridge University Press, 1987) 104-119; J.A. Sharpe, Defamation and sexual slander in early modern England: The church courts at York (York: University of York, 1972) 15; Horodowich, Language and statecraft, 99.

70 Gowing, Domestic dangers, 59-138; Lipscomb, 'Crossing boundaries,' 417; Taylor, 'Women, honor and violence,' 1083 .

$71 \quad$ Dean, 'Gender and insult,' 219, 231; Lesnick, 'Insults and threats,' 71.

72 Angelozzi and Casanova, Donne criminali74.

73 As for example argued by M.R. Greenshields, An economy of violence in early modern France. Crime and justice in the Haute Auvergne, 1587-1664 (Oxford: British Library, 1986) 233 .

74 Gowing, Domestic dangers, 115, 118; Taylor, 'Women, honor and violence,' 1084-1085; Rublack, The crimes of women, 26. 
some of her neighbours shouted "injurious words, treating me like a women with little honour" at Rosa, an unmarried daughter of Domenico Mazzoni. ${ }^{75}$ She had been standing in the doorway of her apartment building talking to a young man she describes as her friend and her neighbours had disapproved of the conversation and, implicitly, what it could lead to. Conversely, sexual probity garnered the same result in a case from 1675. Anna Maria, wife of Angelo Michele Capelli, refused to have sexual intercourse with barber Giovanni Battista Bordani, explaining she was an honourable woman. Anna Maria declared that after this rejection, Giovanni Battista started calling her a puttana (whore), a buzzerona (female sodomite) and similar words, threatening to beat her up because she did not want to submit to his wishes. ${ }^{76}$

More often than not, however, these insults pertained to a wide range of social and economic behaviours outside of the sphere of sexual behaviours. In 1653, Maria, wife of Giovanni Battista Chiarini, was called a buzzarona infame puttana (infamous sodomite whore), alongside other similar words, by the son of a man who had an outstanding debt with her husband. ${ }^{77}$ Similarly, a year earlier the carpenter Horatio Foglia called his direct neighbour Domenica, wife of Battista Secchandi, not only a ladra (thief) but also a puttana after accusing her of stealing wine from their shared cellar. ${ }^{78}$ Aside from disputes over debts and possessions, another example from 1674 demonstrates how sexualised slurs were also used in the context of mundane neighbourhood enmities. The mother and sister of Anna Maria Caballi were coming over to visit her apartment and knocked loudly on the door and windows. These loud noises vexed her neighbours Georgio, Giovanna and Elena Bonetti to such an extent that they started shouting insults at Anna Maria, her mother and sister, saying that they were all whores and scoundrels, even though her "sister was a young honourable single girl."79 Rather than implying knowledge about actual sexual impurity, this case demonstrates how the sexualised rhetoric of honour and dishonour could be employed as a tool in the pursuit of a broader range of social and economic interests.

As a rule, insults against men were more varied. Men were also called bastardo (bastard), becco (cuckold) or becco fottuto (fucking cuckold) in Bologna, but it is clear that these sexual insults were essentially female-centred, aiming

\footnotetext{
75 ASBo, Torrone, 7869-1, fol. 201: "parole ingiuriose trattandomi da donna poco da bene."

76 Asвo, Torrone, 7028, fol. 178-179: "puttana buzzarona e simile, e minaccio di darmi de pugni, perche non volevo acconsentire alle sue voglie."

77 AsBo, Torrone, 6653 , fol. 41.

78 Asво, Torrone, 66o9, fol. 254 .

79 ASво, Torrone, 7028, fol. 8o-81: "con dirci che siamo tutte puttane, e barone nonostante che detta mia sorella sia putta zitella honorata, e da bene."
} 
to ridicule men's affiliation with women who did not adhere to the sexual mores. ${ }^{80}$ Similar to what has been argued for insulted women, these verbal affronts did generally not infer actual sexual transgressions. Again, they consisted of stock insults suitable for a wide spectrum of circumstances, ranging from theft and outstanding debts to noise complaints. For example, in $165^{2}$ Sabattino Alterino caught sight of Anna and her son Pellegrino on the lawn behind his house. Commenting that they would crush his grass, they started calling Sabattino bad words, such as seed of a cuckold thief, and said that his daughters were whores, which offended him because he considered himself an honourable man. ${ }^{81}$

Men often also received non-sexual insults, referring to their honesty or ability to carry out a profession. Men in medieval Todi were often called 'liar', 'thief' and 'crook,' accusations that undermined their economic credibility and called into question their success and stature as a merchant, tradesman, artisan or labourer ${ }^{82}$ In seventeenth- and eighteenth-century Bologna men were also commonly insulted with these economic aspects of their good or bad reputation: ladro (thief), barone (scoundrel), birichino (rascal), poltrone (good-for-nothing), guidone (scumbag) and furbo (crook). For example, Vincenzo Tura was called a scumbag, failure and a traitor (guidone, un fallito, et un traditore) by Nicolo Mini in 1705. He had failed to pay off the still outstanding amount of 30 lire for a house his father had purchased from him, making the references to his economic failure befitting. ${ }^{83}$ In other cases, the connection between the direct meaning of the slur and the behaviour was less clear, suggesting that these verbal affronts could be used at random, and in a range of different combinations.

Injurious words such as ladra (thief), poltrona (good-for-nothing) or barona (scoundrel) were also hurled at women. However, both the late-medieval and early modern Bolognese court records suggest that this non-sexual form of slur was used less commonly for women than for men and, furthermore, that the vocabulary of affront was less varied and more repetitive when directed at women than the insults directed at men. ${ }^{84}$ Alongside gendered differences in the repertoire of verbal affront, part of the reason for the 'semantic poverty' of insults towards women may be found in the magistrates' prosecutorial indifference.

$80 \quad$ Strocchia, 'Gender and the rites of honour,' 54; Dean, 'Gender and insult,' 221.

81 Asвo, Torrone, 66o9, fol. 209: "villanie, cioe razza di becco ladro, et simile, et che ho da figliole che sono puttane," which offended him 'per essere un huomo honorato."

82 Lesnick, 'Insults and threats,' 71.

83 ASBo, Torrone, 76o8-1, fol. 197-198.

84 Dean, 'Gender and insult,' 226; Angelozzi and Casanova, Donne criminali, 75 . 
The criminal court records support the idea that the petty violent acts among the lower classes were generally not a priority to the authorities. Many of the court records merely mention the exchange of 'injurious words' (parole ingiuriose), 'dishonest words,' 'impoliteness's' (villanie) or 'insolent remarks' (insolenze), without specifying what words had been used exactly. When specific slurs were jotted down by the notaries, it was rather imprecise and summarily, with some examples of slurs followed by 'and other similar ones' (ed alter simile). As discussed, the potential harm of verbal injuries to the honour and reputation of individuals and their families was widely recognized. The harsh sentences that the criminal bylaws prescribed bore witness to the fear of violent retaliation and vendetta that insults could bring forth as easily as physical affront could. But while the defamation of a social superior was generally taken very seriously by the authorities, verbal aggressions among commoners of roughly equal status was not. ${ }^{85}$ It was exactly this group that made up the bulk of those appearing before the criminal court. How notaries documented details about their affronts must be viewed within this context.

These mechanisms of judicial disregard were likely exacerbated for women. Women's assumed 'weaker nature' and judicial minority derived from Roman law may well have caused their violent behaviours to have been taken less seriously than men's. ${ }^{86}$ In the Bolognese countryside, the village's local bailiffs (massari) were reluctant ant to relay women's complaints to the criminal court, as their concerns were more likely to be perceived as trivial. ${ }^{87}$ Similarly, the lack of female offenders prosecuted for verbal injury by Venice's Avogaria di comun probably also had less to do with a hypothetical confinement of women to the domestic arena than with a judicial disregard. ${ }^{88}$ It is not difficult to reconcile the notion of a magistracy seeking to protect civic order and the stability of the state with a judicial paternalism towards women probably widely shared among court magistrates. ${ }^{89}$ At times this judicial paternalism resulted in less harsh sentencing, and other times in women not being prosecuted at all.

Most litigants themselves did not seek out the criminal court to pursue their complaints about insults to a full criminal trial either. Some scholars have

85 Burke, The historical anthropology of early modern Italy, 99. For the insults against nobles and state officials that were taken seriously and prosecuted by the state authorities, see Horodowich, Language and statecraft, 105-112.

86 For more on women's legal position according to Renaissance jurists, see Graziosi, 'Fragilitas sexus,' 19-38.

87 Angelozzi and Casanova, Donne criminali, 70, 257.

88 The cautious suggestion regarding women's confinement to the domestic arena was put forward in Horodowich, Language and statecraft, 101.

89 For the notion of judicial paternalism, see Casanova, 'Crimini di donne, giudici benevoli,' 3 . 
argued that taking conflicts to the judicial authorities may have been particularly appealing to those with a marginal position in society. In her examination of sixteenth-century Rome, Elizabeth Cohen asserts that while established householders might resolve attacks to honour through other routes, prostitutes found in the criminal tribunal a 'public and socially sanctioned forum in which to air their grievances and, within the conventions of honour culture, to spread shame on their attackers. ${ }^{90}$ For early modern Bologna there is little evidence that those appealing to the criminal court belonged to a particularly disreputable segment of the urban lower classes. Yet the mechanism that Cohen identifies may be comparable. By bringing their grievances to the criminal court, Bologna's common labourers and small-time artisans hoped to gain additional leverage in often long-term conflicts with their social peers. What they expected from the law was not an intervention by the authorities per se, but an advancement of their extrajudicial settlement options.

While recourse to the criminal court may have been a common strategy to enhance one's social bargaining power, it was also frowned upon on a broader social scale. Such sentiments were not only reflected in disgruntled responses by those incriminated in denunciations, but the political dimension was also in a tangible way incorporated into the vocabulary of verbal affront. There is evidence for early modern Bologna, Rome and Venice that the corpus of insults was complemented with invectives of 'traitor' and, above all, 'spy' (spia). ${ }^{91}$ Spy was a serious insult because it conjured up associations with the inquisition and oppressive social control. ${ }^{92}$ Locally, within the Papal States, the insult furthermore specifically alleged deceitful collusion with the foreign 'operators of justice'; represented in Bologna by the Torrone and its sbirri. Local officials or others working directly for the authorities formed the most obvious target of these slurs. The denunciation by Stefano a Porta, a local bailiff of the Via Nuova in Bologna's inner-mural parish of San Giorgio, from the early 1650 os is illustrative in this regard. While investigating a brawl that had taken place in his district, he encountered the day-labourer Giovanni Monti, who upon questioning started calling him so much as a 'fucking cuckold spy' and a 'thief who was a spy by profession. ${ }^{93}$ People who performed duties for the court, such its messengers delivering court citations, were understandably similarly targeted with these kinds of slurs.

$90 \quad$ Cohen, 'Honor and gender,. 624.

91 Cohen and Cohen, Words and deeds, 159-187; Angelozzi and Casanova, Donne criminali, 76 .

92 Rose, A renaissance of violence, 173; Horodowich, Language and statecraft, 100.

93 АSво, Torrone, 66o9, fasc. 142: "[...] et esso subito mi ha ingiuriato di parole dicendome spia becca fotuta, ladro, dicendome inoltre ch'io vada a fare la spia, ch'è mio mestiere." 
This particular kind of slander extended beyond these actual officials to the wide range of ordinary labourers (textile workers, cobblers, tanners and so on) who merely took recourse to the law. Although this specific form of verbal aggression was most prevalent among male recipients, there is ample evidence that the contempt for cooperating with the criminal court was shared equally by men and women of all social classes. ${ }^{94}$ The example from the beginning of this chapter, in which Angela accused her neighbour Maria of having acted as a spy (fare la spia) after having her incarcerated for her previous misbehaviour, is a good example of this. ${ }^{95}$

The contempt for taking recourse to the law can be attributed to a combination of cultural and political factors. Traditional understandings of honourable behaviour precluded the use of criminal courts. According to the scienza cavalleresca (i.e. the laws of honour which governed gentlemanly conduct first codified in the 155 os but is still widely discussed in eighteenth-century Italy) a man of honour was required to punish offences without recourse to the law because a true gentleman demanded satisfaction for himself rather than punishment by a third party. ${ }^{96}$ Even though these codes formally only pertained to the honour of gentlemen, there were broader social and political tensions that made both conceptions of honour and using the law a contested affair for men and women of all social standings. The use of the Torrone furthermore led to indignation due to its intimate ties to the papal government. Being ruled by priests was widely resented, with the Pope (and consequently Bologna's papal government) being viewed by parts of the population as a foreign despot. ${ }^{97}$ Involving this 'foreign' institution rather than resolving a conflict informally was therefore regarded a deplorable 'collaboration.' Recourse to the law was thus both very efficient particularly because of this external leverage, but also, ultimately, morally reprehensible. However, the deep-seated contempt revealed by the continued use of spia and fare la spia throughout the eighteenth century did not curtail the use of law courts by those seeking to resolve disputes, whether it concerned verbal or physical forms of aggression.

\footnotetext{
94 Angelozzi and Casanova, Donne criminali, 76.

95 AsBo, Torrone, 7869-1, fasc. 163 .

96 Carroll, 'Revenge and reconciliation,' 102, 113.

97 G. Angelozzi and C. Casanova, 'Il tribunale criminale di Bologna,' in M. Cavina (ed.), $L a$ giustizia criminale nell'Italia moderna (XVI-XVIII sec.) (Bologna: Pàtron Editore, 2012) 252253.
} 
Aside from verbal aggression, petty physical violence is increasingly recognised as a regular feature of women's everyday life in the early modern period. Just how regular this violence was, and what this represents in comparison to the figures of other regions, is difficult to ascertain due to differences in source material as well as contemporary classifications. Much of the recent research on women's violence in towns in northern Europe has emphasised women's relatively high shares among offenders of petty violence..$^{98}$ Examining physical violence prosecuted by Rotterdam's (lower) court of correction during the first half of the eighteenth century, Manon van der Heijden argued that women's share among 'fighting' (the least serious category of physical violence she distinguishes) was 42 per cent. ${ }^{99}$ This was significantly higher than the share before the regular criminal courts in Rotterdam and Amsterdam, which amounted to around 6 per cent. Studies on sixteenth- and eighteenth-century Paris suggest that women's proportional share as offenders of petty violence ranged between five and 17 per cent. ${ }^{100} \mathrm{~A}$ broader definition of petty violence is used in the scholarship on 'assault' on England, which includes threatening gestures and words alongside physical violence. ${ }^{101}$ In his examination of the prosecution of assault before two summary courts in London between 1784 and 1796, Drew Gray found that 31 per cent of those accused of assault were female. ${ }^{102}$

In Bologna women were also more prominent among offenders of petty violence. While only between 2.5 and 5 per cent of homicide defendants consisted of women, they made up about 21 per cent of all offenders of petty violence among the denunciations. A categorisation closer to that of 'assault' results in an average of 26 per cent between the mid-seventeenth and the mid-eighteenth

98 Hurl-Eamon, Gender and petty violence; Kilday, Women and violent crime; Van der Heijden, Women and crime,; Walker, Crime, gender and social order, 25.

99 The average share of women accused of the broad category of violence (including fighting with another person and the destruction of property and belongings) prosecuted by Rotterdam's correctional court was $24 \%$. See Van der Heijden, 'Women, violence and urban justice,' 84 .

100 A. Farge and A. Zysberg, 'Les théâtres de la violence à Paris au Xviıre siècle,' Annales. Économies, sociétés, civilisations 34:5 (1979) 986; Roussel, 'La description des violences féminines,' 71 .

101 Gray, 'The regulation of violence in the metropolis,' 78.

102 Deduced from table 5.4 based on the minute books of the Guildhall and Mansion House justice rooms in Gray, Crime, prosecution and social relations, 108. 
century. ${ }^{103}$ In 1675 , no less than 39 per cent of the offenders of petty violence consisted of women.

The involvement of early modern European women in petty acts of aggression has also been quantified based on particular judicial procedures that bound people to keep the peace. These measures were used for a wide range of acts of physical and verbal aggression similar to the English category of assault. Studying London's recognizances between 1680 and 1720, Jennine Hurl-Eamon found that female assailants made up one-third of the total. ${ }^{104}$ For Scotland between 1750 and 1815 , Anne-Marie Kilday has calculated that no less than 41 per cent of the so-called 'Letters of Lawburrows' were brought and granted against women. ${ }^{105}$ Both for England and Scotland it has been argued that these measures were particularly preferred by those seeking redress for assault when the assailant had been a woman. ${ }^{106}$ The accessibility, efficiency and effectiveness, as well as the low costs associated with this form of prosecution may well have contributed to the popularity of this judicial procedure among early modern women. As I have argued earlier, the seventeenth- and eighteenth-century Bolognese peace injunctions functioned in a similar way to these English and Scottish measures and produce strikingly similar figures. In Bologna, 44 per cent of the offenders who were made to promise not to injure or harm the other person again consisted of women accused of petty physical or verbal aggression.

The proportional share of petty violence among the total of reported crimes also speak to the importance of these forms of aggression in the everyday lives of Italian women. Studies on Italian towns during the Renaissance and early modern period have demonstrated the continuous high share of primarily petty violence among the recorded crimes of women and men. This stood in marked contrast to most northern European towns, where property crimes often ranked highest on the criminal courts' dockets. ${ }^{107}$ In fourteenth- and fifteenth-century Florence between a quarter and half of all urban female offenders were brought before the court for assault and battery. ${ }^{108}$ Non-lethal

103 In the Bolognese case this would include the categories of physical violence not resulting in life-endangering wounds, threats and other forms of verbal aggression as well as the recordings of precetti issued for a range of undefined physical or verbal acts of violence.

104 Hurl-Eamon, Gender and petty violence, 67.

105 Kilday, Women and violent crime, 94.

106 Hurl-Eamon, Gender and petty violence, 130; Kilday, Women and violent crime, 94; Shoemaker, Prosecution and punishment, 207.

107 See for example J. Kamp, Crime, gender and social control in early modern Frankfurt am Main (Leiden: Brill, 2019) 68; I.A. Cameron, Crime and repression in the Auvergne and the Guyenne, 1720-179o (Cambridge: Cambridge University Press, 2011) 179.

108 Cohn, 'Women in the streets, women in the courts,' 26. 


\begin{tabular}{|c|c|c|c|c|}
\hline & \multicolumn{2}{|c|}{ Female defendants } & \multicolumn{2}{|c|}{ Male defendants } \\
\hline & $\begin{array}{l}\text { Denunciations } \\
\qquad(\mathrm{N}=\mathbf{2 4 1})\end{array}$ & $\begin{array}{l}\text { Processi } \\
(\mathrm{N}=70)\end{array}$ & $\begin{array}{l}\text { Denunciations } \\
\qquad(\mathrm{N}=903)\end{array}$ & $\begin{array}{l}\text { Processi } \\
(\mathrm{N}=1287)\end{array}$ \\
\hline Lethal violence & - & $6 \%$ & $1 \%$ & $9 \%$ \\
\hline $\begin{array}{l}\text { Physical violence } \\
\text { with danger to life }\end{array}$ & $2 \%$ & $13 \%$ & $7 \%$ & $19 \%$ \\
\hline $\begin{array}{l}\text { Physical violence } \\
\text { without danger to } \\
\text { life }^{\mathrm{a}}\end{array}$ & $34 \%$ & $10 \%$ & $34 \%$ & $9 \%$ \\
\hline Verbal aggression ${ }^{b}$ & $19 \%$ & $4 \%$ & $15 \%$ & $7 \%$ \\
\hline $\begin{array}{l}\text { Undefined violence } \\
(\text { precetto })^{\mathrm{b}}\end{array}$ & $26 \%$ & $4 \%$ & $10 \%$ & $1 \%$ \\
\hline $\begin{array}{l}\text { Other crime } \\
\text { categories }\end{array}$ & $18 \%$ & $63 \%$ & $33 \%$ & $55 \%$ \\
\hline Total & $100 \%$ & $100 \%$ & $100 \%$ & $100 \%$ \\
\hline
\end{tabular}

SOURCE: SAMPLE 1 AND 2 COMBINED (SEE APPENDIX), COUNTED BY DEFENDANT

a 'Petty physical violence'

b 'Petty violence' in its broadest sense includes the categories of petty physical violence, verbal aggression and the undefined violence

violence was also the most common crime that brought men and women before Viterbo's fifteenth-century podestarial court. ${ }^{109}$ This observation is echoed by the few examinations of later periods. In sixteenth- and seventeenth-century Rome, the largest proportion of deviant behaviour by women who appeared before the Governor's criminal court concerned brawls and other forms of petty violence. ${ }^{110}$

Bologna's criminal casebooks also brimmed with denunciations concerning violent altercations such as scuffles. As in other Italian towns, petty violence constituted a significant share of the crimes reported to Bologna's criminal court: among the denunciations, nearly 8 o per cent of all female and over $5^{8}$ per cent of all male offenders had been accused of non-fatal, physical violence without life-endangering wounds (see table 15). Significantly more so than

109 Rizzo, 'Donne e criminalità,' 13.

110 C. Vasta, 'Per una topografia della violenza femminile (Roma, secoli XVI-XVII),' Genesis 14:2 (2015) 67 . 
verbal affronts or homicide, petty physical altercations formed the largest cause for bolognesi's encounters with the law.

Like verbal injuries, these scuffles, brawls and assaults were only prosecuted to a small degree. This is clearly visible in the diverging shares of the different crime categories during the criminal court process as demonstrated in table 15 . While hundreds of bolognesi flocked to a court's notary each year to denounce these types of violent altercations, these non-fatal attacks among the lower classes very rarely led to the start of an inquisitorial trial as they were largely considered too insignificant to prosecute. ${ }^{111}$ That the Torrone's statutes specifically instructed its judges not to pursue so-called 'minor crimes' such as insults, threats and non-life-endangering fights among the lower classes, is a telling example of this attitude. ${ }^{12}$

Violence was not condoned or ignored, however, even if it was 'petty' in character. Communities in early modern Europe did their best to maintain law and order through a range of formal and informal sanctions. ${ }^{113}$ Both the Bolognese authorities' active encouragement of peacemaking among its plaintiffs and defendants as well as the stream of bylaws issued concerning weapon regulations underscore this point. For those men and women who came to the court, too, the insistence on pressing charges reveals a popular concern over petty violence, as did the frequent appeal to and issuing of the aforementioned peace injunctions for petty violence. ${ }^{114}$ If the denunciations are evidence of popular perceptions of misbehaviour, women's violence was clearly considered an unwelcome aggression deemed worth denouncing to the court.

Recognising that women were considered capable of a significant degree of violence, scholarship from the past decade has commenced re-evaluating the relationship between gender and violence. Recently various scholars have argued that petty violent offences were, in many ways, 'not sex-specific' or even 'ungendered.'115 Factors that contributed to this assessment were the ways in

\footnotetext{
111 This also happened in England, see Hurl-Eamon, Gender and petty violence, 3;

112 Angelozzi and Casanova, La giustizia criminale a Bologna nel XVIII secolo, 391.

113 Dinges, 'The uses of justice,' 159-175; Kilday, Women and violent crime, 93.

114 Hurl-Eamon, Gender and petty violence, 4; J.M. Beattie, 'Violence and Society in Early Modern England,' in A.N. Doob and E.L. Greenspan (eds.), Perspectives in criminal Law: Essays in honour of John L. J. Edwards (Aurora: Canada Law Book, 1984) 42.

115 Hurl-Eamon, Gender and petty violence, 3, 66, 70, 88; J. Turner, 'Summary justice for women. Stafford Borough, 1880-1905,' Crime, history \& societies 16:2 (2012) 55.
} 
which violence was described in criminal court records, as well as the form and seriousness of this violence. As elsewhere in early modern and modern Europe, Bolognese casebooks reveal that men assaulted in greater numbers than women, but that when women did commit an assault there were many similarities to be found.

Although both men and women were capable of inflicting serious damage, the relative 'pettiness' that can be considered the most typical aspect of the reported violence of men and women. The pettiness related both to the causes of the altercation as well as the physical repercussions. The denunciation by Gio Batta Spinelli against barber Antonio Leli on 19 August 1705 is typical in this regard. ${ }^{116}$ When the two men passed one another on the street, Antonio bumped into Gio Batta, which caused Gio Batta to fall on the ground. He disgruntledly showed his now dirty hand to Antonio and asked if he wanted to be soiled as well, after which Antonio gave him two blows with his barber scissors. According to Gio Batta this wounded him in his right shoulder and left arm, wounds that the court officials would have been able to see at the time of the denunciation a day later if he "had not had himself medicated." The records indeed note vulneribus minime; minor wounding.

A similar situation is found some twenty-odd years later, when Anna Vandoni's tenants were yelling at each other all night and she asked them if they were not ashamed of all the obscene words that came out of their mouths. ${ }^{117}$ Anna Marchesini, one of these tenants, had responded by throwing a foot stove in her face, hurting her - even though the wounds could not be seen anymore when the denunciation was made one day later. While the Torrone's prosecutorial effort concentrated on the more severe forms of violence, by far the largest share of violent behaviours reported to the court had led only to minimal or no visible physical wounds at all.

How men and women fought, and how this may have differed between the sexes, has been subjected to important scrutiny the past decades. In her work on crime and gender in seventeenth-century Cheshire, Walker explicitly dismisses both the stereotypical notion of women's violence as a modern 'catfight' involving "a few scratches, a slap in the face, or pulling hair" and the

116 ASBo, Torrone, 76o8-1, fol. 76 .

117 АSво, Torrone, 7869-1, fol. 19. "Hieri sera all'ave maria senti che le sopradette gridavano con Lucia Giordani pigionante nella loro casa a causa che tutta notte andava delle gente su per le scale della medema, il che sentita da me, dissi, che vera non era vergogna per le gran parole oscene [... e] che pertanto le medeme tutte uscite mi cominciorono a strappazzare con parole ingiuriose e la sopradetto Anna mi tiro lo scaldino, che haveva in mano, e mi feri nella fronte, la qual ferita vs non puol vedere, atteso i medicamenti." 
association of weapons with distinctly masculine combat as somewhat anachronistic. ${ }^{118}$ She instead argued that male and female defendants, as proportions of the total number of defendants of their own sex, were equally likely (just over 40 per cent of the total) to be prosecuted for armed assault. Percentages for other regions and time periods diverge. In eighteenth-century Rotterdam, only a quarter of the male defendants are reported to have used a weapon compared to ten per cent of the women. ${ }^{119}$ Moreover, percentages as low as four per cent (for female defendants) to seven per cent (for male defendants) have been found for seventeenth- and eighteenth-century London. ${ }^{120}$ In seventeenth- and eighteenth-century Portsmouth, 16 per cent of the male offenders of physical assault and 15 per cent of the women used weapons. ${ }^{121}$

Bologna's early modern criminal court records suggest that weapons were commonly used in physical altercations. Over one-third of the women reported to have engaged in physical violence and 57 per cent of the male defendants were described as having used a weapon in their affront. Even among petty physical violence cases, just under half of the total defendants had used a weapon.

High rates of weaponry use in physical violence have also been found in examinations of violence in Rome and southwestern France: 42.5 per cent of the cases in Rome were committed with arms between 1561 and 1584, and Julius Ruff found that a staggering 63.3 per cent of homicide and physical assault trials in the Sénechausséés of Libourne and Bazas between 1696 and $1789 .{ }^{122}$ The relationship between the high rates of weapon use in southern Europe and the prevailing culture of violence is not clear-cut. Some scholars noted early modern Italians' particular "comfort with violence and a familiarity with weaponry that pervaded all levels of society."123 At the same time, it has been argued that the proactive enforcement of weapon-possession laws in Italian towns like Bologna is commonly overlooked in discussions such as these. Gregory Roberts recently contended that the strict regulation of the right to bear arms through police patrols and a government licensing regime from the mid-thirteenth cen-

118 Walker, Crime, gender and social order, 77-78. Walker here quotes Spierenburg, 'How violent were women?', 10. Also insisting that women were usually unarmed is S. Amussen, "Being stirred to much unquietness": Violence and domestic violence in early modern England,' Journal of women's history 6:2 (1994) 75 .

119 Van der Heijden, 'Women, violence and urban justice in Holland,' 88.

120 Hurl-Eamon, Gender and petty violence, 73.

121 See table 1 in J. Warner, J. Riviere and K. Graham, 'Women behaving badly. Gender and aggression in a military town, 1653-1781,' Sex roles $5^{2}$ (2005) 294.

122 Blastenbrei, 'Violence, arms and criminal justice,' 75; Ruff, Crime, justice and public order, 79 .

123 Rose, A renaissance of violence, 90. 
tury onwards "resulted in the arrest, trial, and conviction of scores of men, including political elites, each year." ${ }^{24}$ Attempt by Bologna's legislators to suppress interpersonal violence through the active policing of arms-bearing, and the keen interest in recording factors such as weapon use, may thus also have played an important role in explaining the high degree to which weapons were mentioned in the criminal court records.

Women did not solely rely on the sharpness of their tongues, nor did they refrain from using weapons as much as stereotypes would suggest. Nevertheless, many scholars have observed clear gender differences in the types of weapons that male and female protagonists used. Among weaponry types, swords and firearms are the most notable and distinctly gendered, as they were nearly exclusively used by men. ${ }^{125}$ This was also the case in Bologna. Swords and other long-bladed weapons were not just the particular preserve of men, but of nobles and their retainers. As elsewhere in early modern Europe, the right to bear these kinds of arms was reserved for the nobility of the senatorial class and their licensed servants. ${ }^{126}$ In the eyes of papal justice, the possession of arms constituted a crucial cause of the endemic violence. In a bid to improve public order and mitigate violence in Bologna's streets and villages during the seventeenth century, weapons became the pillars of the public order legislation from the sixteenth-century onwards. ${ }^{127}$ The ambition to curb violence was reflected in the 1610 Bando Generale, which prohibited the carrying of a wide range of arms in the city and countryside. ${ }^{128}$ The carrying of swords without a licence was also forbidden on pain of the loss of the arm, a fine of 25 gold scudi and three pulls of the cord (tratti di corda). ${ }^{129}$ The right to carry swords was outlawed on broad social levels, but a massive number of civic officials and notables were exempted from its provisions, beginning with the Anziani and the Tribunale delle Plebe and including the counts, senators, judges, soldiers, notaries, captain gatekeepers, artisans, and citizens and inhabitants who returned from outside the city. ${ }^{130}$ The special status of these officials and notables was largely upheld in later edicts throughout the seventeenth century, although further restrictions and conditions were imposed upon them

\footnotetext{
124 Roberts, 'Vendetta, violence, and police power,' 5

125 Hurl-Eamon, Gender and petty violence, 74; Walker, Crime, gender and social order, 79.

126 Rose, A renaissance of violence, 187.

127 Ibidem, 230; Blastenbrei, 'Violence, arms and criminal justice,' 75; Bando generale Serbelloni 1756 , chapter XLVI, No. 7 , page 75 .

128 Bando generale Giustiniano 1610, chapter XXIV, page 43-51.

129 Ibidem, 47.

130 Ibidem, 47-49.
} 
regarding the bearing of other blades such as daggers, the length and blunting of blades, and the licensing of servants. ${ }^{131}$

Firearms, another male preserve, were also heavily regulated. In Bologna throughout the seventeenth and eighteenth centuries, archebuses were often subject to an absolute ban. Under the section of prohibited arms in the 1610 criminal bylaws, the arms mentioned first were the archibugietti - longer than three palms and suitable to wound from far away - which were absolutely forbidden. ${ }^{132}$ The punishments for the bearing of these rudimentary firearms ranged from death by hanging for the archibugietti corti da ruota, and a fine of 200 scudi for the archibugio longo a ruota and pistols, to three pulls of the cord for the arcobugio da fuoco. ${ }^{133}$

Despite these harsh prescribed punishments, it has been argued that firearms were nevertheless readily available either through the widespread licensing system if not through the black market. ${ }^{134}$ In their campaign against bandits, the Torrone decreed in 1614 the obligation of all contadini in Bologna's rural surroundings to keep in their house "at least one, and preferably two, loaded wheel-lock archebuses, and to carry one with them at all times when out in their fields and around their villages."135 Due to the many disorders and homicides that accompanied the rise of firearms ownership, the decree was reversed within two and a half years. However, the ubiquity of the firearms continued to haunt the Torrone, as men continued to use them in their fights and murders throughout the seventeenth and eighteenth centuries. ${ }^{136}$ The high number of citations issued on a daily basis by the criminal court's lawmen for unlicensed weapons demonstrated a continuous ubiquity of these arms among the male Bolognese populace. ${ }^{137}$

While the use of swords and firearms was thus distinctly reserved to men, both men and women used a broad range of items in their violent altercations (see table 16). Together, swords and firearms only made up a quarter of the weapons used by men in Bologna. With their specific connotations of noble (the swords) and pre-meditated violence (the archebuses), these arms were not necessarily the most representative for men's quotidian violence, neither

$131 \quad$ Rose, A renaissance of violence, 187-188.

132 Bando generale Giustiniano 1610, chapter XXIV, no.2, page 43.

133 Ibidem, 43-45.

134 Rose, A renaissance of violence, 117.

135 ASBo, Legato Bandi, 1600-1700, bando of 7 June 1614, as cited in Rose, A renaissance of violence, 53-54.

${ }_{13} 6$ For a detailed examination of the predominance of archebuses as weapons in the prosecution of long-standing conflicts resulting in death, see Rose, A renaissance of violence, 79-140.

137 Ibidem, 187. 
Weapons used in reported physical violence, ca. 1655-1755

\begin{tabular}{|c|c|c|c|c|c|c|c|c|c|c|c|}
\hline \multirow[b]{2}{*}{$\begin{array}{l}\text { Female } \\
\text { defendants } \\
(\mathrm{N}=54)\end{array}$} & $\begin{array}{l}\text { Firearm } \\
\text { ० } \% \%\end{array}$ & Edged $^{a}$ & \multicolumn{2}{|c|}{ Work tool'b } & \multicolumn{2}{|c|}{ Houseware $^{c}$} & \multicolumn{2}{|c|}{ Stick } & \multicolumn{2}{|c|}{ Stone } & Misc. \\
\hline & ○ $\quad$ o\% & $1120 \%$ & 8 & $15 \%$ & 21 & $39 \%$ & 5 & $9 \%$ & 7 & $13 \%$ & $2 \quad 4 \%$ \\
\hline $\begin{array}{l}\text { Male } \\
\text { defendants } \\
(\mathrm{N}=317)\end{array}$ & $196 \%$ & $14144 \%$ & 38 & $12 \%$ & 20 & $6 \%$ & 41 & $13 \%$ & 53 & $17 \%$ & $2 \%$ \\
\hline
\end{tabular}

\section{SOURCE: SAMPLE 2 AND 3 (SEE APPENDIX)}

Included are the categories of lethal physical violence, serious physical violence and petty physical violence. Not included in this table are the allegedly unarmed assailants: 133 women, 214 men. The distribution is roughly the same for petty physical violence alone.

a Includes swords, daggers and knives. Out of the 141 male defendants recorded to have used edged weapons, 49 used swords $(35 \%)$

b Included are tools carried outside of the household setting, often referred to as tools for certain professions such as 'cobbler's knife' or 'instruments', hammers, scissors, sickles and shovels

c This category includes a range of items found around the house such as foot stoves, rolling pins, pots and pans and pieces of furniture

quantitatively nor contextually. For the spontaneous rises to violence that characterised much of the quotidian altercations filling the Torrone's court records, aggressors reached for their knives, their tools or other handy implements they had on them or could find in their nearby surroundings. ${ }^{138}$

Various work tools were among the items weaponised in the event of escalated disputes. In proportional terms these tools were used equally often by men and women, making up 15 per cent of women's weapons and 12 per cent of men's. They broadly reflected their occupations and work environments, as they were either picked up during the fight or, in case of the smaller items, were carried around as part of the offender's profession. For men the tools they used in their violent altercations reflected their work in stables (shovels, pitchforks, horse bridles and leather whips), agriculture (sickles), textile (textile rods, spools and scissors) and as artisans (hammers), among which the tools of cobblers were most prominent (cobbler knives, leather punchers and moulds). Women's tools also refer to their textile work (textile rods, spindles) and furthermore included sickles and shovels.

A broad range of knives were utilised as weapons in violence. Various kinds of knives and daggers (though rarely the elite stiletto) made up 29 per cent of the weapons mentioned in men's violence when excluding swords, and 20 per cent of women's. Knives were ubiquitous in the urban space, as they were far

${ }_{138}$ This was also the case for male-on-male killings, see Rose, 'Homicide in North Italy,' 180. 
less regulated than for example firearms and swords and furthermore had many functions. Men and women of all social stripes were accustomed to carrying a blade, ostensibly for cutting bread or eating and only occasionally, when quarrels escalated, for fighting.

Literature commonly associates certain weapons with particular kinds of social segments. While swords were at least in normative terms reserved for gentlemen and their aides, knife fighting was affiliated with the population's lower social strata. ${ }^{139}$ In Bologna, too, those fighting with swords clearly belonged to a higher social segment and included a variety of those exempted from the ban on weapons, such as a marquis, chevaliers, a notary's son and seven nobles' servants. ${ }^{140}$ Those fighting with daggers resemble the group of the sword fighters, including one gentleman (jailed nine times previously, however), a knight and three servants, as well as various artisans. ${ }^{141}$ The knife fighters on the other hand clearly belonged to the broad band of urban artisans and labourers, such as cobblers and various types of textile workers. Based on his research on knife-fighting in seventeenth- and eighteenth-century Amsterdam, Pieter Spierenburg asserted that knife fighters may have occupied a social position along the border of the 'respectable and disreputable segment' of the urban lower classes. ${ }^{142}$ How to determine whether this was true for Bologna is difficult to say. What the court records do reveal is that only two of the knife fighters were known to have been jailed before. One of them was Francesco Antonio Angeloni, an arms keeper, who had wounded an innkeeper, and the other was tanner Girolamo Romagnoli, having spent 17 days in the bishop's jail for an unspecified offence. ${ }^{143}$ Some knife fighters were also described as having the reputation of a scoundrel (barone di piazza), but the large majority of them did not.

The social profile of knife fighters resembled that of those wielding sticks. Sticks as well as stones were among the more 'circumstantial' weapons, as they

139 Boschi, 'Knife fighting in Rome, 138; P. Spierenburg, 'Knife fighting and popular codes of honor in early modern Amsterdam,' in P. Spierenburg (ed.), Men and violence. Gender, honor and rituals in modern Europe and America. (Columbus: Ohio State University Press, 1998) 109-110.

The category of 'swords' includes 2 sables. Among the 31 known professions of the sword fighters (out of 43), there were also various merchants (5), (master) artisans (9) as well as various seemingly lower-class professions such as cleaners (2), gong farmers (2) and even a vagabond that fought with swords that they had either stolen, acquired through the licensing system or through the black market. For 14 sword fighters, the occupation was unknown.

141 The 19 'dagger fighters' record 10 professions: 1 gentleman, 1 chevalier, 3 servants, 2 barbers, 2 coopers and 1 painter. 
were often picked up during a fight rather than carried about the person. They made up significant proportions of weapons used by both men and women: nine per cent of the women and 13 per cent of the male fighters employed sticks in their fights. According to Spierenburg's theory, sticks were predominantly used by the more respectable people who refused to become involved in knife fights and instead, when threatened or challenged, tried to ward off the danger by other means such as a stick. ${ }^{144}$ Not many of the stick-wielding bolognesi appeared to have had a criminal past: only one of them has been reported as having just been released from prison for an unspecified crime. ${ }^{145}$ But while some of the stick fighters indeed attained respectable social positions (for example as church guardians and gilders), the majority appeared to have belonged to the same, ambiguous group of artisans (primarily coopers, bricklayers and various apprentices), complemented by porters and an unemployed beggar. What does stand out among the stick fighters is the number of apprentices and porters among them, a peculiarity shared by those that hurled stones.

Stones formed opportune weapons for men and women alike, making up 13 per cent of women's weapons and 17 per cent of men's. The streets were littered with stones, roof tiles and pottery shards and it therefore comes as little surprise that people in early modern Italy were often reported to have carried them and used them in their fights. In seventeenth-century Rome, police "were forever stopping" people with rocks on them; in their pockets, under their cloaks, up their sleeves, in their work aprons or even in the lining of their hats. ${ }^{146}$ Much of the appeal of stones as weapons lay in their ubiquity, as they could easily be picked up during a brawl. In Bologna on 9 February 1706, the angered barber's apprentice Gio Battista Rampone, for example, spontaneously threw a stone at the back of Giovanni Alberti, a matrass maker's apprentice, after he had played a prank on him. ${ }^{147}$ Similarly, Domenico and Marta Pongetti, two textile cutters, took offence at their co-worker Giuseppe Fiorentini's jokes on 6 August $1755 .{ }^{148}$ Marta hurled a stone at him, hitting Giuseppe in the eye.

A relatively small but culturally significant proportion of the fights with stones concerned the so-called sassaiole or sassate. A continued series of edicts issued against these rock-throwing battles in many Italian towns throughout the centuries attest to the failure to push rock-throwing out of the civic

\footnotetext{
144 Spierenburg, 'Knife fighting and popular codes of honor,' 109-110.

145 ASBo, Torrone, 6653, fasc. 2.

146 R. Davis, 'Say it with stones. The language of rock-throwing in early modern Italy,' Ludica $10(2004) 113$.

147 ASво, Torrone, $7608-1$, fol. 176 .

148 АSво, Torrone, 8171-1, fol. 157.
} 
mainstream. The unsuccessful outlawing of this practice in Perugia (also part of the Papal States) reconstructed by Davis mirrors the situation in Bologna, where both the criminal bylaw of 1610 and that of 1756 reiterated the hefty fines and public corporal punishment prescribed to those that participated in, or went to see, the rock-throwing battles. ${ }^{149}$ Yet, as in Perugia, the early modern Bolognese court records contain many references to these forbidden practices, particularly because the treating doctors were required to denounce their patients - nearly always claiming to be an innocent bystander - to the Torrone. The denunciation by Gaetano Ordelassi is no exception and is indeed in many ways emblematic of these rock-throwing battles. ${ }^{150}$ On 6 August 1674 this eightyear-old boy found himself before one of the court's notaries with a barber's report describing the grave head wound he had sustained the previous Saturday. He described how many boys were battling each other near the burial grounds for those that were hanged. One of their stones hit Gaetano in the middle of the head, wounding him 'with some danger to life.' He denied having participated, however, claiming that he just happened to be there, coincidentally sitting somewhere nearby.

While stones were used as weapons by men and women alike, the fare a sassate is considered to be a crime typically committed by groups of young men and boys. ${ }^{151}$ Rather than merely functioning as weapons that caused physical injury, Davis argued that the fights with stones must also be viewed as a 'complex means of discourse' that involved moral hurt, personal vilification and had an anti-authoritarian, anti-papal connotation. ${ }^{152}$ Being hit by stones in these battles was considered shameful as it likened the victim to an uncivilised beast. ${ }^{153} \mathrm{Although}$ women certainly did use stones as weapons in their violent one-on-one altercations, there is little evidence that they partook in the local legacies of the sassate. Bolognese court records as well as Perugia's police accounts seem to support the notion that the offenders were young men. Although systematic inquiries into the age of offenders were lacking in the Bolognese court dossiers, the groups of stone-throwers were invariably referred to as ragazzi, i.e. boys. Often, though not always, victims were also boys themselves. The denunciation by Girolamo Blasio is illustrative in this regard. ${ }^{154}$

\footnotetext{
149 Bando generale Giustiniano 1610, chapter XXv, no. 5-7, page 52-53; Bando generale Serbelloni 1756, chapter LXII, no. 8-9, page 112; Davis, 'Say it with stones,' 119.

15 O AsBo, Torrone, 7028 , fol. 5 o.

151 Angelozzi and Casanova, Donne criminali, 83.

152 Davis, 'Say it with stones,' 118, 127.

153 Ibidem, 114-115.

154 ASBo, Torrone, 6620, fol. 273.
} 
After being treated for a dangerous head wound, he identified the principal perpetrator as a boy - "big like me" - of around twelve years old. ${ }^{155}$

Scholarly literature commonly contrasts knives, swords and firearms to the pottery, dishes, pots and pans that women are believed to have employed frequently. ${ }^{156}$ In Bologna various types of housewares were indeed common among the arms that women wielded amidst their violent confrontations. Pots and pans, rolling pins, bottles, water buckets, chairs and food items made up no less than 39 per cent of their weapons (see table 16). The importance of these kinds of items is striking when compared to men's use of housewares, which was limited to a comparatively meagre six per cent of their weapons.

Despite the false sense of domesticity that the category of housewares may instil on the violent affairs of women, these altercations were not necessarily as harmless as they may seem. Pieces of furniture (like a chair) were used to beat one another, which could cause significant bodily harm. A very significant number of women - constituting nearly half of the items within the category of housewares - also flung foot stoves at their adversaries. The trial against Ursula Bagliardi on 5 February 1755 is a telling example of the damaging potential of this kind of weapon. ${ }^{157}$ Her neighbour, the married spinner Barbara Lambertini, had to be treated in the hospital for a serious head wound after getting into a fight with Ursula. Barbara had seen her sixteen-month-old toddler being hit with a stone by Ursula's young daughter and smacked the girl in the face to discipline her. After finding out about these events, Ursula sought out Barbara and threw a foot warmer still full with fire (pieno difuoco) in her face. According to the surgeon who treated Barbara, this resulted in life-endangering wounds. Other victims of still lit foot stoves describe similar unnerving effects. In 1725, for example, Maria Corellini threw one at her neighbour Antonia Vignecchi, angered by having to pay more rent, causing Antonia to end up with wounds all the way from her mouth to her stomach. ${ }^{158}$ Moreover, it should not be forgotten that in over half of the reported cases women had assaulted others with knives, work tools as well as sticks and stones they found on the ground. As Walker argued for seventeenth-century Cheshire, both women and men armed themselves with whatever they had at hand. ${ }^{159}$

155 Ibidem: "[...] non conosco detto ragazzo, ne si chiama, ma è grande come sono, et puole havere dodici anni in circa [...]."

${ }_{15} 6$ Van der Heijden, 'Women, violence and urban justice,' 88; Hurl-Eamon, Gender and petty violence, $72-73$.

157 ASво, Torrone, 8166-2, fasc. 5 o.

158 Asво, Torrone, 7869-1, fol. 3 .

159 Walker, Crime, gender and social order, 79 . 
Despite the normative prescriptions that continue to colour historians' perceptions of women's violence, there is little evidence that women's behaviour was characterised by a particular weakness or passivity. At the same time, it is important to emphasise that men's violence as a whole was by no means always deadly, nor did the type of weapons they used diverge inherently from those employed by women. To understand the meaning and purpose of women's violence in early modern Italian society, the next sections will explore the social profiles of offenders and victims, which are believed to have been highly gendered, as well as where and when violence occurred.

Who were the men and women involved in violence? Much of our understanding of the social composition of violent offenders is based on studies on lethal violence. These studies emphasise that the majority of murderers were (and are still) young men between the age of twenty and twenty-nine, whose victims were often of the same age and sex. ${ }^{160}$ While no scholar disputes the predominance of men among killers, the focus on homicide has led to very particular, arguably inaccurate characterisation of quotidian violence in early modern Europe. Due to its function as a forum for conflict resolution, the Torrone's casebooks allow us to also gauge large numbers of non-fatal violent altercations. The examination of the social characteristics of those involved in physical and verbal aggression will demonstrate the prevalence of violence among broad sections of the population.

Ascertaining the social positions of offenders and victims of violence is no easy feat. As others have noted, the characteristics of wealth and status that marked social division during the early modern period were fluid, and the language of social description was imprecise. ${ }^{161}$ Even though the 'quality' of a person could be a decisive factor in sentencing, most early modern criminal court records did not systematically record socioeconomic characteristics of defendants and plaintiffs. For this reason, markers of identity such as provenance and age, while meaningful and interesting, are beyond the scope of this section. What will be treated here are the occupational and marital status of the plaintiffs and defendants, who they fought and what relationships existed among them.

\footnotetext{
160 R. Muchembled, A history of violence: From the end of the Middle Ages to the present (Cambridge: Polity, 2012) 9 .

161 Hitchcock and Shoemaker, London lives, 4.
} 
The occupations of fighters recorded in the Bolognese casebooks represent a broad section of society. For their livelihood, defendants of both sexes pursued a wide range of professions, from servants, labourers, hawkers, and struggling textile workers, to shopkeepers, skilled master artisans and even some public officials, as well as nobles. In this regard the Bolognese situation mirrors that of other late medieval and early modern towns, in which violence originated not from fringe groups as much as from the centre of communities. ${ }^{162}$ Far from being marginalised to the social periphery, violence belonged to the cultural repertoire of most classes and groups in premodern Europe. Craftsmen, especially apprentices but also masters, have been identified as the core group among urban perpetrators.

Criminologists, sociologists and historians generally agree that the men who were predominantly responsible for violent offences were young and unmarried. ${ }^{163}$ This has been contended for towns all over early modern Europe, as well as for earlier and later time periods. With less than ten per cent of men's marital statuses defined, the Bolognese casebooks exclude any real proof to the contrary. Women's marital ties were recorded regularly, since their social standing is believed to have been much more contingent on their relationship to other men. ${ }^{164}$ Married women constituted by far the largest proportion of those involved in violence (over two-thirds of the assailants whose civil status was recorded), followed by unmarried (one-eighths) and lastly widowed women.

Other scholars also observed that the women coming before criminal courts for violent offences were often married. ${ }^{165}$ Walker noted that married women constituted over half of all female defendants in assault cases in seventeenthcentury Cheshire. ${ }^{166}$ Similarly, Beattie found that in the urban parishes of eighteenth-century Surrey over 6o per cent of women accused of crimes against the person were married. ${ }^{167} \mathrm{He}$ furthermore argued that many of these married, violent women belonged to the more settled and established positions in the

162 Schwerhoff, 'Social control of violence,' 227, 241.

163 Ruff, Violence in early modern Europe, 125; Eisner, 'Long-term historical trends,' 113-115; P. Spierenburg, A history of murder. Personal violence in Europe from the middle ages to the present (Cambridge: Polity, 2008) 90-91; Mantecón, 'The patterns of violence in early modern Spain,' 245, 248; Schwerhoff, 'Social control of violence,' 227; Blastenbrei, Kriminalität in Rom, 95.

164 Castan, Les criminels de Languedoc, 36-37.

165 Beattie, 'The criminality of women,' 101-102, 115; Kilday, Women and violent crime, 94; Walker, Crime, gender and social order, 76 .

166 Wives constituted 54.2 per cent, spinsters 35.6 per cent and widows 10.2 per cent of defendants according to Walker, Crime, gender and social order, 76 .

167 Beattie, 'The criminality of women,' 101-102, 115 . 
community, with a good proportion being married to 'men of some substance,' rather than being part of the "dispossessed and rootless sections of society."168 In Bologna too, the embeddedness of these women in the community may have been an important part of the reason why it was that their violence specifically came to the notice of the courts. Given the Torrone's functioning as a forum for conflict resolution, charges generally served the purpose of extracting reparations for the damage done, monetary or other. Litigation of this kind bore most meaning when it occurred within the context of community.

An interesting feature of the Bolognese case - and arguably more broadly of the premodern Italian one - was the violence perpetrated by members of the nobility. Although labourers and artisans had invariably constituted the largest group of perpetrators of quotidian violence, recent historical works have revealed how early modern states saw noble violence as a threat to the maintenance and expansion of their authority. ${ }^{169}$ Looking back on the past centuries of private vendettas, Legate Serbelloni's 1756 summation of the criminal bylaws describes factional violence as "destroying human society."170 This perceived threat was also reflected in the criminal court records. For towns all over medieval Europe, scholars have observed an overrepresentation of the upper classes in violent behaviours compared to their demographic proportions. ${ }^{171}$ Although long-term comparisons on the social status of offenders are lacking, it has been suggested that the involvement of the upper classes in criminal violence declined sooner in northern than in southern Europe. ${ }^{172}$ While noble violence in England, for example, is assumed to have declined after 1550, upper-class violence remained prevalent in Italy well into the early modern period.

Criminal court records indeed reveal a significant concern with the violence of notables. According to a study on seventeenth-century Bologna, nearly half of the homicide victims in the urban and rural territory had consisted of members of the nobility and their servants. ${ }^{173}$ In Siena, in 16oo, nobles committed around 30 per cent of the homicides prosecuted, but this share declined

168 Ibidem, 102.

169 Cummins, 'Forgiving crimes in early modern Naples,' 255.

170 Bando generale Serbelloni 1756, chapter VI, no. 3, page 12

171 Eisner, 'Long-term historical trends,' 116-117; G. Ruggiero, Violence in early Renaissance Venice (New Brunswick: Rutgers University Press, 1980); S.R. Blanshei, 'Crime and law enforcement in medieval Bologna,' Journal of social history 16:1 (1982) 123; B. Hanawalt, Crime and conflict in English communities: 1300-1348 (Cambridge: Harvard University Press, 1979) 131 .

172 See for a summary of this evidence Eisner, 'Long-term historical trends,' 117.

173 Rose, A renaissance of violence, 93. 
afterwards: to 16 per cent by the mid-century and to eight per cent by $1700 .{ }^{174}$ Nobles also figured less and less prominently in the violence recorded in the urban Bolognese casebooks. Defendants with noble statuses were explicitly labelled as such on the cover pages of investigation dossiers. For offenders of all types of violence, over half of these mentions were found in the 1655 sample year. ${ }^{175}$ In that year, nearly one-seventh of the violent offenders consisted of nobles or their servants; bravi, socci and servitorii. The share of nobles among violent offenders in Bologna dropped to a mere two to three per cent in the following century. ${ }^{176}$ While the premeditative violence of the nobility had put its definite mark on the seventeenth century, scholars have argued that love rivalries, futile arguments and escalated drunken brawls typified violence the century afterwards. ${ }^{177}$

The upper-class violence, as well as the papal government's campaign against it, was deeply entrenched in Northern Italy's political history. The reestablishment of papal authority in northern Italy from the fifteenth century onwards has been called 'a violent project' as it was confronted with continued resistance by local oligarchies that wished to retain their power. ${ }^{178}$ This resistance and particularly the refusal of Bologna's leading Bentivoglio clan to adapt to papal rule led to the conquering of the city 1506 as well as to the expulsion and hanging of dozens of leading, rebellious oligarchs throughout the sixteenth and seventeenth century. But the nobility's violence was not only directed against the nascent papal rule: they also fought each other. Under papal rule factional identities (Republican and Oligarchic) that had dominated the late-communal period continued to divide Bologna's nobility. ${ }^{179}$ Many of the edicts issued throughout the seventeenth century therefore aimed to curb the

174 O. Di Simplicio, Peccato, penitenza, perdono: Siena 1575-180o. La formazione della coscienza dell'Italia moderna (Milan: Franco Angeli Storia, 1994) 103, 130 as quoted in Hanlon, 'Violence and its control,' 148.

175 In a representative sample of all urban processi collected for the years 1655, 1675, 1705, 1725 and 1755, 13 out of 588 identified offenders indicted for physical or verbal aggression were explicitly named as $D$. (don, notable) on the cover page of the trial dossier. Seven of these offenders had offended in the sample year 1655, 2 in 1675, 1 in 1705, 2 in 1725 and 1 in 1755 .

176 In the 1655 sample, 20 out of 144 offenders with an indication of profession or estate belonged to the nobility or their retainers. For 1675 the sample includes only 2 references (out of 100 offenders), and in the periods after that only 7 (out of 267) offenders are categorised as such.

177 Angelozzi and Casanova, La giustizia criminale a Bologna nel XVIII secolo, 183 .

178 Rose, 'Homicide in North Italy', 35-37.

179 Ibidem, 31, 38. 
nobility's independence, power and violence in the city of Bologna and its rural hinterlands. ${ }^{180}$

There is important evidence that Bologna's factitious local nobility had indeed been pacified by the turn of the eighteenth century. Angelozzi and Casanova attributed this 'disciplining' of the nobility to a programme of re-education in enlightenment values and a new chivalric code that emphasised courtly civility over violent revenge as the defining trait of the nobleman. ${ }^{181}$ Others, however, contended that the Bolognese nobility were not so much civilised or re-educated, as that the more violent ones were prosecuted and banished to beyond the borders of the Papal States. ${ }^{182}$ This culminated in the expulsion of a large swathe of the local nobility in 1664 . The 'retreat of the nobility' from violence - much later than in much of northern Europe - should be seen in this light. 183

As elsewhere in early modern Europe, violence did not commonly challenge presiding hierarchies and structures of social and political authority. ${ }^{184}$ This meant that the victims of violence by and large belonged to similar social groups as their offenders. Public officials or other figures of authority who endured violence as a kind of occupational hazard are largely responsible for the middle and wealthier classes being very slightly better represented among victims of violence. The efforts of local bailiffs in conducting criminal investigations were not always appreciated, after all. ${ }^{185}$ Court messengers, delivering the Torrone's citations summoning suspects or witnesses of a crime to report to the court, were also ill-received. After receiving such a citation in 1706, Giovanni Gambalunga, a seller of chestnut cookies, did not want to accept the citation and was even more disinclined to pay the courier the twenty-six quattrini demanded for his services. ${ }^{186}$ When the courier tried to seize a towel as collateral, Giovanni was angered further, raised his arm to punch him and shouted at him to let go of his possessions, leading the cursore to scurry away and lodge a complaint. Acts of aggression against 'social superiors' nevertheless only represent a minority of the cases recorded by the criminal court. Overall, most perpetrators of violence belonged to the lower reaches of society and offended

180 G. Hanlon, 'The decline of violence in the West: From cultural to post-cultural history,' English historical review 128:531 (2013) 390; Hanlon, 'Violence and its control,' 144.

181 Angelozzi and Casanova, La nobiltà disciplinata, 243-288.

182 Rose, 'Homicide in North Italy,' 2, 228.

183 Eisner, 'Long-term historical trends,' 117.

184 Schwerhoff, 'Social control of violence,' 227-228; Rose, A renaissance of violence, 36.

185 Asвo, Torrone, 66o9, fasc. 142. "[...] et esso subito mi ha ingiuriato di parole dicendome spia becca fotuta, ladro, dicendome inoltre ch'io vada a fare la spia, ch'è mio mestiere."

ASBo, Torrone, $7608-1$, fol. 235 . 
those of roughly equal status. ${ }^{187}$ More typical of everyday violence were the brawls that erupted among artisans, peddlers and porters during their daily affairs, such as social discourtesies, money issues, drunkenness and competition for work. In 1706, for example, Domenico Maria Giacometti lost out on an employment opportunity to his fellow wine porter Giuseppe Tomasi because he had a nosebleed. ${ }^{188}$ Not long after, he spitefully drew his knife and stabbed Giuseppe with it. Cases against female aggressors reveal similar patterns. In a denunciation from 1724, vegetable seller Fiorina was fed up with labourer Giacomo Ruspulini's lingering around her stall and insinuated he should get on with it and purchase something before he died. ${ }^{189}$ Giacomo sneered he would erect the gallows for her husband then, if she had one, after which Fiorina hit him in the face with her stool. With a bloodied face he hurried away, first to the market chief and then to the hospital to have his wounds treated. While women's violence did also generally adhere to hierarchies of class and social status, this did not necessarily prevent them from offending against men. The diminishing share of the nobility and their retainers is nevertheless important to the understanding of the changing face of violence during the seventeenth and eighteenth centuries.

This brings us to the question of who fought whom in early modern Bologna. Scholars have observed that in early modern European towns in the majority of cases the patterns of interaction in quarrels reveal 'gender homogeneity.'190 This meant that men generally faced men and women opposed other women. The idea that women's violence should be categorised as 'same-sex' violence has nevertheless been questioned. Seventeenth-century Cheshire, for example, revealed an entirely different image of violence: here nearly threequarters of the victims in female-perpetrated assaults were men. ${ }^{191}$ Among the recognizances too, men comprised nearly half of those who sought the security of peace against women. The costs of prosecuting by indictment in the English system - for which men are assumed to have possessed greater means - may partially explain why women assaulted men to this degree, it has been argued that but the patterns of women's violence were also informed by

187 Dean, Crime and justice in late medieval Italy, 171; Ruff, Violence in early modern Europe, 125; Rose, A renaissance of violence, 36, 90; Becker, 'Changing patterns of violence and justice,' 283; G. Ruggiero, Violence in early Renaissance Venice (New Brunswick: Rutgers University Press, 1980) 120.

188 АSво, Torrone, $76 \circ 8-2$, fasc. 3 .

189 ASво, Torrone, 7869-1, fol. 2.

190 Schwerhoff, 'Social control of violence,' 227; Spierenburg, 'How violent were women?,' 21; Van der Heijden, 'Criminaliteit en sexe,' 29-30; Vasta, 'Per una topografia della violenza femminile,' 6 o.

191 Walker, Crime, gender and social order, 79-80. 
household structures and obligations. ${ }^{192}$ Walker argued that wives exercised de facto control of the domestic space and defended household boundaries against men, who were "numerically more likely than women to be aggressors in such situations." ${ }^{193}$ It was thus in the role of the mistress of the household that women most often became involved in disputes that the criminal courts heard about; when household concerns were at stake.

For early modern Bologna, the truth lies somewhere in the middle between the 'gender homogeneity' proposed by most scholars and Cheshire's high share of female-on-male assaults. The majority of violent protagonists offended against adversaries of their own sex, but women's aggression was slightly less gender-specific than men's. Men - alone or in groups - constituted nearly onethird of the victims of women's verbal and physical aggression recorded in the criminal court documents, while women were only assaulted by men in onefifth of the cases. If women had a male accomplice, they were more likely to assault a man than vice versa, but this did not mean that women merely had an 'assisting role,' as some scholars have suggested. ${ }^{194}$ In 1654 cobbler Vincento di Stantini declared that he had been assaulted by bread seller Leonora and her assistant Lorenzo after complaining he did not like the bread and wanted his money back. ${ }^{195}$ Lorenzo had stones in his hand, but it was Leonora who had hit Vincento with a stick, making her the clear protagonist in this violent altercation. Men, however, were more likely to co-offend with male accomplices, fought in proportionally larger groups, and under all circumstances predominantly offended other men. In proportional terms, men's violence in Bologna was more 'same-sex' than women's was.

The relatively lower levels of male-on-female violence reflect contemporary cultures of violence in which men frequently fought each other, as well as gendered methods of conflict resolution and prosecution. Rates of men victimising women would have definitely been higher had spousal violence been brought to the attention of the Bolognese criminal court more often and consistently. In Italy men had the right to chastise their wives and the law did little to correct men who abused this right. Several studies on the subject suggest that the right to chastise was enacted in legislation, respected by the law courts, and assumed by husbands in everyday marital life. ${ }^{196}$ In its most extreme form, the husband's right to discipline his wife functioned as an extenuating factor or

\footnotetext{
192 Ibidem, 8o.

193 Ibidem, 52, 76, 80.

194 Angelozzi. and Casanova, Donne criminali, 113-117.

195 Asвo, Torrone, 6653, fol. 131.

196 T. Dean, 'Domestic violence in late-medieval Bologna,' Renaissance studies 18:4 (2004) 527; Cavina, Nozze di sangue, 30; Lombardi, 'Marriage in Italy,' 112-113.
} 
even an acquittal in trials involving wife-killing. In non-lethal forms of domestic violence, too, Italian men brought before the court often appealed to their natural right of correction. ${ }^{197}$ While 'moderate correction' largely went uncontested, uncontrolled wife-beating was condemned by family members and neighbours alike. ${ }^{198}$ Domestic violence nevertheless rarely came to the notice of the Torrone, and when it did these complaints were generally either rejected due to insufficient evidence, or they were settled semi-voluntarily in the form of reconciliation. ${ }^{199}$

Since 'matters of the family' were not considered to be the business of the criminal court, domestic violence by women was also underrepresented in the court dossiers. ${ }^{200}$ Aside from the habit of dealing with these situations informally, underreporting of women's misdeeds was furthermore heightened by perceptions of the unimportance of women's violence as well as humiliation. ${ }^{201}$ The case of apprentice Francesco Vitali - one of the few domestic cases recorded among the Torrone's case files - supports this view. When Vitali claimed to have acquired his head wound through an unlucky fall, the surgeon responsible for medicating him deemed his explanation implausible and reported him to the criminal court. ${ }^{202}$ Only days later, after hearing that his wife had taken various items from their house during his hospital stay, he admitted to lying about the cause in his earlier declaration and that it actually had been his wife who had beaten him on the head with a hammer. The general reluctance to involve the secular criminal court in these potentially embarrassing matters of the family - experienced by both the authorities and the victims themselves - provides a contextual explanation for the public character of the violence recorded in Bologna's criminal court files.

The overwhelming majority of cases documented by the Torrone concerned what Kilday has called 'communal' violence; disturbances that occurred not between members of the same household or family, but between neighbours,

197 Cavina, Nozze di sangue, 111.

198 Hacke, Women, sex and marriage, 141.

199 Cavina, Nozze di sangue, 111, 115; Casanova, Crimini nascosti, 81.

200 There is not a lot of evidence that ecclesiastical courts actively sought to interfere in these matters either. Cavina, Nozze di sangue, 111, 115; Casanova, Crimini nascosti, 81. For a more elaborate discussion of the Italian criminal justice system's treatment of domestic violence in a comparative perspective, see M. van der Heijden and S. Muurling, 'Violence and gender in 18th-century Bologna and Rotterdam,' Journal of social history 51:4 (2018) 695-716.

201 Angelozzi and Casanova, Donne criminali, 120; Eibach, 'Böse Weiber und grobe Kerle,' 680; Beattie, 'The criminality of women,' 87 .

ASBo, Torrone, 8171-1, fig7. 
co-workers, with customers, and so on. ${ }^{203}$ Even though the likelihood of violence among strangers was probably higher on urban streets and in town alehouses than in close-knit rural surroundings, studies suggest that most people involved in quarrels in early modern towns generally knew each other. ${ }^{204}$ For seventeenth-century Bologna, Rose has demonstrated that most homicides occurred within known relationships, where the victim and offender were at the very least acquainted with each other. ${ }^{205}$ In early modern Bologna, too, the court records suggest that the vast majority of violent altercations in the city of Bologna occurred between people who knew each other at least by name and acquaintance, rather than between strangers. Only about one-tenth of the urban Bolognese offenders were entirely unknown to the victim. ${ }^{206}$

Rather than complete strangers, offenders and victims of violence were commonly relatives, fellow professionals, acquaintances and neighbours. These relationships, broken down in table 17, could be gathered for nearly half of the sampled denunciations and processi for physical and verbal aggression between the mid-seventeenth and mid-eighteenth century. This data testifies to the similarities between the everyday violence committed by men and women, demonstrating that the overwhelming majority of reported violence in Bologna had taken place outside of household or family relations. Although studies on lethal violence suggest that women probably committed violence against 'intimate victims' such as children, husbands and servants, the same cannot be assumed for violence in general. ${ }^{207}$ Instead, women, like men, had many other opportunities for socialisation and conflict outside of the 'domestic realm' in the city.

In proportional terms, the relationships forged by women's activities in the urban economy were at least equally important as violent conflicts within the sphere of the family. Similar to other textile manufacturing towns such as Turin and Milan, women's labour force participation was high in Bologna: according to estimations nearly 64 per cent of Bolognese women aged eleven and

203 Kilday, Women and violent crime, 52, 92.

204 Schwerhoff, 'Social control of violence,' 227; Eisner, 'Long-term historical trends,' 119.

205 Rose, A renaissance of violence, 91, 98, 103.

206 From the $45^{1}$ offenders whose relationship to the victim was known, 45 declare not knowing the offender at all, not even from sight.

207 Howard, 'Crime, communities and authority,' 85-86; Kilday, Women and violent crime, $5^{2-}$ 53; O. Hufton, 'Women and violence in early modern Europe,' in F. Dieteren and E. Kloek (eds.), Writing women into history (Amsterdam: Historisch Seminarium van de Universiteit van Amsterdam, 1991) 82-84; Beattie, 'The criminality of women,' 83-84; Spierenburg, A history of murder, 16. 
TABLE 17 Social and economic relationships between offenders and their victims, ca. 1655-1755

\begin{tabular}{|c|c|c|c|c|c|}
\hline & & \multicolumn{2}{|c|}{ Women } & \multicolumn{2}{|c|}{ Men } \\
\hline & & $\#$ & $\%$ & $\#$ & $\%$ \\
\hline \multicolumn{2}{|l|}{ Family } & 8 & $10 \%$ & 40 & $12 \%$ \\
\hline \multirow{2}{*}{ Neighbourhood } & Neighbours & $5^{8}$ & $57 \%$ & 38 & $11 \%$ \\
\hline & Landlord-tenants & 8 & $8 \%$ & 5 & $1 \%$ \\
\hline \multirow[t]{4}{*}{$\begin{array}{l}\text { Work and the } \\
\text { urban economy }\end{array}$} & $\begin{array}{l}\text { Employer- } \\
\text { employee }\end{array}$ & 1 & $1 \%$ & 19 & $5 \%$ \\
\hline & $\begin{array}{l}\text { Colleagues-com- } \\
\text { petitors }\end{array}$ & 3 & $3 \%$ & 37 & $11 \%$ \\
\hline & Vendors-clients & 3 & $3 \%$ & 24 & $7 \%$ \\
\hline & Creditor-debtor & 2 & $2 \%$ & 23 & $7 \%$ \\
\hline \multicolumn{2}{|c|}{ Undefined friends \& acquaintances } & 17 & $17 \%$ & 117 & $34 \%$ \\
\hline \multicolumn{2}{|c|}{ Unacquainted } & 1 & $1 \%$ & 44 & $13 \%$ \\
\hline \multicolumn{2}{|l|}{ Total } & 102 & $100 \%$ & 347 & $100 \%$ \\
\hline
\end{tabular}

SOURCE: SAMPLE 2A AND 2B (APPENDIX), COUNTED BY DEFENDANT

Calculations based on denunciations and processi of physical violence, verbal aggression and issuances and breaches of the precetto criminale (de non offendendo), where sufficient information was provided on relationships between offender and victim

over had paid employment. ${ }^{208}$ More than half of them worked in the textile industry. Most women thus had an economic life of their own, be it in their husband's business or outside of it. Orsola, who made and sold headdresses out of her home, for example, mistreated Paolo Salani, a citizen of Bologna, and his female acquaintance who wanted to return one of the three headdresses bought the week before. When setting a price, they had done so based on a total purchase of three, and Orsola did not agree with the restitution of one third of the price. With "bad words, and little respect" she mistreated Paolo and his acquaintance and started pushing both of them aggressively. ${ }^{209}$

Female fighters also came in the shape of market vendors competing in the market place and defending their economic interests with words and deeds.

208 Palazzi, 'Tessitrici, serve, treccole,' 366-367; D'Amico, 'Shameful mother,' 110; Zucca Micheletto, 'Reconsidering women's labor force participation rates,' 211.

209 ASво, Torrone, 8171-1, fol. 8o. 
A good example of the fierce competition over preferred places on the market comes from Elisabetta Spadoni and her husband Melchiore, a goldsmith, who together threatened to strike another goldsmith by the name of Gasparo Cavalli with a cane if he would not give up the market stall she had set her eyes on. ${ }^{210}$ Similarly, Barbara Romare was pulled by the hair, dragged across the piazza and scratched in the face by another vendor who was upset with her for selling similar wares near to her stall at too cheap a price. ${ }^{211}$ Examples such as these echo women's broader socioeconomic roles in the fabric of early modern towns.

Aside from the similarities, various gender differences in the perpetratorvictim relationships can be distilled from the court records. First, the group of undefined friends and acquaintances was much larger for male than for female offenders ( 34 compared to 17 per cent). Many of the conflicts in this category occurred in the context of sociability, for example in and around inns as well as on the street. Conflicts revolved around losing and cheating at gambling as well as jokes and drunken banter taken the wrong way. Although women certainly visited taverns too - the Bolognese criminal court records feature several of these visits - the world of sociability is assumed to have differed for men and women. ${ }^{212}$ More so than for men, the presence of women in public spaces in early modern Italian towns was shrouded by normative restrictions, which when violated could not only impact her perceived respectability but also made her liable for criminal prosecution. When women fought with present and former friends and acquaintances, they instead appear to have primarily done so in and around the home. In the criminal records women are often reported to have hung out around houses, for example leaning out of the window or standing in the doorway. This will be examined in more detail in the next section that discusses the importance of houses as spaces for women's violence. The prevalence of neighbours and the neighbourhood may therefore help to explain the relatively lower share of undefined friends and acquaintances for female offenders.

Second, while it is important to recognise that women's violent altercations also emerged from their activities in the urban economy, it is noteworthy that

\footnotetext{
210 ASBo, Torrone, 8171-1, fol. 128.

211 ASBo, Torrone, $8171-2$, fasc. 31. "[...] quale venuta meco a contesa a motive della nostra uniforme professione, pretendo essa dassi le mie a troppo vile prezzo [...]."

212 S.K. Taylor, 'Women, honor, and violence in a Castilian town, 1600-1650,' The sixteenth century journal 35:4 (2004) 141; Howard, 'Crime, communities and authority', 76-77; M. Prior, 'Private spheres and public records. Reconstructing women's history for the early modern period,' in F. Dieteren and E. Kloek (eds.), Writing women into history (Amsterdam: Historisch seminarium van de Universiteit van Amsterdam, 1990) 61.
} 
these kinds of relations were recorded more frequently for male than for female fighters (30 compared to 9 per cent). It does not seem unlikely that this difference was related to the gendered division of labour. As mentioned before, a significant proportion of men and (even more so) women in early modern Bologna found employment in the urban textile industry, as spinners, weavers, hosiery manufacturers and seamstresses. ${ }^{213}$ But while male artisans worked on heavier silks of greater value on shops, factories and mills, lighter and simpler textiles were left to women's 'domestic' production. ${ }^{214}$ The largest majority of the female textile labourers therefore worked from home through a sort of putting-out system organised by merchant contractors. Although the testimonies in the criminal records reveal that women did not necessarily always ply their trades on their own, this gendered labour division likely affected the extent to which socialisation and consequently conflicts occurred between coworkers or between employers and employees. It furthermore reminds us that to understand the social dynamics of violence, the spatial environment needs to be taken into consideration.

\section{The Gendered Geography of Violence}

Another important issue in the debate on the gendered nature of crime relates to the places in which violence took place. The early historiography on the relationship between gender and early modern urban geography was characterised by a strong emphasis on a gendered divide between the public and private spheres. Based on didactic and prescriptive literature as well as travel descriptions, the idea was put forward that women, because they were secluded and enclosed by moral norms, were typically absent from the public spaces. Dennis Romano's work has been particularly influential for early modern Italy. ${ }^{215}$ As sites of business and politics, he described Renaissance Italy's piazzas, bridges, canals and streets as male spaces, whereas female spaces were thought to have been more confined to the 'home.' Other studies have on the other hand indicated that, especially for non-elite men and women, such a binary divide between public and private spaces was an anachronistic projection of ideals that

213 For 1726 it has been calculated that women made up 62 per cent of the urban weavers in Bologna, see Guenzi, 'L'identità industriale,' 464.

214 Palazzi, 'Tessitrici, serve, treccole,' 368-369; Guenzi, 'La tessitura femminile,' 251-253; Dumont, 'Women and guilds,' 7, 9; Terpstra, 'Working the cocoon,' 48-49.

215 D. Romano, 'Gender and the urban geography of Renaissance Venice,' Journal of social history 23 (1989) 339-350. 
did not reflect the complex realities of past everyday lives. ${ }^{216}$ As Cohen suggested, women, like men, regularly used many if not most of the urban spaces, and for various reasons: to attend religious or civic events, to go to church, to work, for recreation and for transgressive behaviour.

In spite of this criticism, the 'domestic space' has continued to be equated with the 'typical female arena,' also in relation to violence. Men are usually seen as being able to navigate between public and private places, committing violence in both realms, while for women it is often the setting of the household that is emphasised. ${ }^{217}$ Various studies on women's lethal violence in the early modern period, have stressed the 'domestic nature' of this violence, stressing that women's conflicts were based on the tensions and conflicts of 'household life and relationships' and that they primarily made 'intimate victims' such as family members and servants, whereas for men this was much more varied. ${ }^{218}$ Explanations as to why this was the case have revolved around early modern women's more restricted social and economic roles. ${ }^{219}$

It would be erroneous to extrapolate this 'domestic character' of lethal female violence to violence as a whole. Indeed, while it is uncontested that women's killings generally took place within the household setting, there is abundant evidence that the much more common acts of non-fatal violence did not. In early modern Bologna, the vast majority (59 per cent) of female defendants were accused of offending outside the house. Furthermore, both accused male and female fighters victimised non-family or household members, even within the house. The acts of violence that were brought to the

216 Cohen, 'To pray, to work, to hear, to speak,' 294; A. Jacobsen Schutte, 'Society and the sexes in the Venetian Republic,' in E.R. Dursteler (ed.), A Companion to Venetian History, 140o1797 (Leiden: Brill, 2013) 363; A. Vickery, 'Golden Age to separate spheres? A review of the categories and chronology of English women's history,' The historical journal 36 (1993) 383414 .

217 P. Spierenburg, 'Masculinity, violence, and honor: An introduction,' in P. Spierenburg (ed.), Men and violence. Gender, honor and rituals in modern Europe and America. (Columbus: Ohio State University Press, 1998) 17; M. Wiener, 'The Victorian criminalization of men,' in P. Spierenburg (ed.), Men and Violence: Gender, Honor, and Rituals in Modern Europe and America (Columbus: Ohio State University Press, 1998) 207; Boschi, 'Knife fighting in Rome,' 144; Walker, Crime, gender and social order, 33, 37, 76; C.R. Corley, 'On the threshold. Youth as arbiters of urban space in early modern France,' Journal of social history 43:1 (2009) 144; Howard, 'Crime, communities and authority', 85-86.

218 Howard, 'Crime, communities and authority,' 85-86; Kilday, Women and violent crime, 53; Spierenburg, 'Masculinity, violence, and honor,' 16; Walker, Crime, gender and social order, 135; Hufton, 'Women and violence in early modern Europe,' 82-84; Beattie, 'The criminality of women,' 83-84; J.S. Cockburn, 'Patterns of violence in English society: homicide in Kent, 156o-1985,' Past \& Present 130 (1991) 95.

Kilday, Women and violent crime, 57. 
TABLE 18 Locations of violence before the Torrone, ca. 1655-1755

\begin{tabular}{|c|c|c|c|c|}
\hline & \multicolumn{2}{|c|}{ Female defendants $(\mathrm{N}=120)$} & \multicolumn{2}{|c|}{ Male defendants $(\mathrm{N}=484)$} \\
\hline & $\#$ & $\%$ & $\#$ & $\%$ \\
\hline House & 49 & $41 \%$ & 79 & $16 \%$ \\
\hline $\begin{array}{l}\text { Street (incl. markets, } \\
\text { squares and outside public } \\
\text { buildings) }\end{array}$ & 65 & $54 \%$ & 228 & $47 \%$ \\
\hline Inn/tavern & 4 & $3 \%$ & 70 & $14 \%$ \\
\hline Shop/workshop & 2 & $2 \%$ & 76 & $16 \%$ \\
\hline Church & - & - & 29 & $6 \%$ \\
\hline Misc. & - & - & 2 & ०\% \\
\hline
\end{tabular}

SOURCE: SAMPLE 2A AND 2B (APPENDIX)

Calculations based on denunciations and processi for (predominantly) all degrees of physical violence as well as verbal aggression and issuances and breaches of the precetto criminale (de non offendendo)

criminal court's notice were largely communal events in which women sought violent redress for their disputes under the gaze of others.

Examinations of towns elsewhere in early modern Europe also note this publicness of most of women's reported violence. For eighteenth-century Scotland, Kilday found that while homicides by women were largely confined to mariticides (the killing of husbands), the overwhelming majority of common assault cases perpetrated by women were in fact committed outside of the domestic sphere, stressing its communal character. ${ }^{220}$ In Rotterdam's eighteenthcentury so-called fight books almost all (95 per cent) of the female aggressors acted outside of the home. ${ }^{221}$ Finally, in sixteenth- and seventeenth-century Rome, nearly two-thirds of women's violence that came before the Governor's court was committed on the city streets and squares that also formed the stage of men's violence. ${ }^{22}$ Since petty violence was much more common than homicide, for women as well as for men, it can be argued that the communal context was much more typical for female violence as a whole than its' supposed 'domestic nature.'

220 Kilday, Women and violent crime, 52, 92.

221 Van der Heijden, 'Women, violence and urban justice,' 19.

222 Vasta, 'Per una topografia della violenza femminile,' 69. 
Although the violence of men and women largely took place outside of houses, they nevertheless constituted important sites of conflict. With 41 per cent of women's violence occurring in a house (as opposed to male defendants' 13 per cent), this was particularly true for female fighters. But most of the violence that took place in these houses should not be categorised as private, domestic disputes. As is known, the early modern house was not a private domain in a modern sense of the word, as there was no strict spatial divide between working and living. ${ }^{223}$ Aside from the artisan's workshops and inns in which families often both worked and resided, the organisation of Bologna's textile industry furthermore ensured that many of women's economic contributions were made from houses. As a site where violence erupted, the court records reflect this connection between women's work and the house: the aforementioned denunciation by Paolo Salani against Orsola concerning the headdresses she made and sold out of her apartment is a notable example..$^{224}$

Houses furthermore had social functions, which formed important contexts in the eruption of violence. The fights reported to the criminal court above all concerned acquaintances and community-members and the 'after-party' of weaver Anna Grilli and her husband is a rather exceptional yet telling example of in-house sociability. ${ }^{225}$ On Saturday 6 September 1755, Anna, her unnamed husband, her sister Margarita and some other unnamed women had frequented a tavern nearby their home and around its closing hours, on the fourth hour of the night, her husband decided to invite some of the tavern-goers over to their house for some more drinks. One of the guests who came along was Guido Gennasi. He had already had an altercation with the women before, commenting on their drunken, unladylike behaviour which he believed to be below their level. Being invited over to the house, he took aside Anna's young sister, Margarita, and confronted her again while armed with a knife. This enraged the already drunk Anna, who - nicknamed La diavoletta (the little she-devil) for good reason - responded by saying she did not tolerate such behaviour from him, after which she threw a pair of scissors (candle snuffer) across the

223 For an elaborate discussion of public and private spheres in the early modern period, see J. Eibach, 'Das offene Haus. Kommunikative Praxis im sozialen Nahraum der europäischen Frühen Neuzeit,' History \& Archaeology 38:4 (2011) 621-664; S. Muurling and M. Pluskota, "The gendered geography of violence in Bologna, 17-19th centuries," in D. Simonton (ed.), Routledge history handbook of gender and the urban experience (Abington: Routledge, 2017) 153-163; E.S. Cohen, and T.V. Cohen, 'Open and shut: The social meanings of the cinquecento Roman house,' Studies in the decorative arts 9 (2001-2002) 61-84; A. Cowan, 'Gossip and street culture in early modern Venice,' Journal of early modern history $12(2008) 314-315$.

224 ASBo, Torrone, 8171-1, fol. 8 o.

225 ASBo, Torrone, $8175^{-2}$, fasc. 7 . 
room, unfortunately missing its target (Guido), into the face of another male guest (Pietro Berti) who was standing in the doorway. While exceptional in her ferocity, this case clearly demonstrates how houses could function as contested sites of sociability.

While the social functions of the house remain understudied, the importance of the more 'public' sites of sociability in engendering particularly men's violence has been widely acknowledged. ${ }^{226}$ Together, taverns, shops and workshops, and (most commonly the exterior of) churches were the sites of roughly one-third of the recorded violent disputes by male assailants compared to onetenth of the female fighters. Though not overly important in quantitative terms, ale-houses have been understood as particularly significant for men and, allegedly, their violent 'performance' of masculinity. ${ }^{227}$ With taverns came joking, drinking, smoking, dancing and gambling with peers, and it was these rituals that according to scholars produced masculinity.228 In his research on the socio-cultural meanings of spaces in eighteenth-century Frankfurt, Joachim Eibach has argued that it was this symbolic meaning of the tavern that made them highly contested spaces. Seemingly trivial conflicts concerning payment of the bill, rude jokes and accusations of cheating in games were therefore always - in some way or another - about honour. A Bolognese example serves to illustrate this point. Whilst playing the hand game of the Morra, a very fast game infamous for raising tempers, Bartolomeo Boscardini accused fellow player Antonio Marco Pallati of cheating, and after a back and forth of insults Bartolomeo was stabbed with a knife. ${ }^{229}$ A crucial aspect of most of these brawls was that they were instigated by insults and challenges made in a public place. Recognising that reliability and trustworthiness were regarded as important features of a man's honour and reputation, violence could be an appropriately masculine response to avoid the loss of face in the presence of others. $^{230}$

226 J. Eibach, 'Violence and masculinity,' in P. Knepper and A. Johansen (eds.), The Oxford handbook of the history of crime and criminal justice (Oxford: Oxford University Press, 2016) 240; Eisner, 'Long-term historical trends,' 119-121.

227 Howard, 'Crime, communities and authority', 76; S. Rau, 'Public order in public space: Tavern conflict in early modern Lyon,' Urban history 34:1 (2007) 102-103; Eibach, 'Böse Weiber und grobe Kerle,' 678; Schwerhoff, 'Social control of violence,' 229; Rose, A renaissance of violence, 115-116; S. Amussen, 'Punishment, discipline and power. The social meaning of violence in early modern England,' Journal of British studies 34:1 (1995) 24-26.

228 Eibach, 'Böse Weiber und grobe Kerle,' 678; F. Nevola, 'Street life in early modern Europe,' Renaissance Quarterly 66:4 (2013) 1337; АSBo, Torrone, 8171-1, fol. 49, 157.

229 АSво, Torrone, 8171-2, fol. 6.

230 Walker, Crime, gender and social order, 37. 
Despite the historiographical tendency to describe taverns in relation to violence as quintessential 'male spaces', the court records do contain examples of women acting aggressively there. The denunciation against Margarita Borsi, a married spinner, made to the Torrone on 30 September 1754 demonstrates this. ${ }^{231}$ According to the plaintiff, the Bolognese lumberjack Alessio Corsini, he was sharing a drink with Margarita - whom he assumed to be a prostitute (donna di mala vita) - in the Osteria della Pellegrina when another man tried to join the two. According to his account, he told the other man to leave them alone, after which Margarita suddenly took out her knife and stabbed him in the face three times. Margarita herself admitted to stabbing Alessio "a few times," but insisted it was because she overheard him telling his three friends that he wanted to take her up to his room. Trying to escape the situation, she walked away, but Alessio grabbed her headdress, slapped, pushed and started choking her, and she declared only stabbed him to liberate herself.

Criminal court records like these show that women were indeed present in taverns: sometimes as perpetrators of violence and, arguably more often, as victims (commonly as personnel) and witnesses (as guests). Scholars like Eibach generally assume that their presence was both quantitatively modest as well as normatively frowned upon. ${ }^{232}$ As has also been argued for German and English towns, unaccompanied Italian women who visited taverns were looked upon with suspicion, particularly regarding their moral status. ${ }^{233}$ The case of Margarita and Alessio echoes these normative ties, as Alessio automatically assumed she was a prostitute because she was there by herself. The normative restrictions were backed up by many of the Italian cities' criminal bylaws: respectable women should be accompanied in public spaces by male kin, or were otherwise considered to be donne di mala vita (supposedly bad women, prostitutes) and could be subjected to punishments ranging from public whipping to exile. ${ }^{234}$ Although these bylaws were not actively enforced, they essentially criminalised women's unescorted mobility in certain places and at certain times. It is therefore no surprise that scholars have argued that women's social lives revolved more around houses - their own and those of others - while men gravitated more towards taverns, piazzas and other open spaces. ${ }^{235}$

\footnotetext{
231 АSBo, Torrone, 8171-1, f23.

232 Joachim Eibach also found women primarily as victims and witnesses to violence in taverns. See Eibach, 'Böse Weiber und grobe Kerle,' 678.

233 Ibidem; Prior, 'Private spheres and public records,' 61; Angelozzi and Casanova, Donne criminali, 104.

234 Angelozzi and Casanova, Donne criminali, 104.

235 Taylor, Honor and violence, 141, 176; Howard, 'Crime, communities and authority,' 76-77; Prior, 'Private spheres and public records,' 61.
} 
Streets, fairs and markets have been recognised as notable contexts for contests about masculine honour and authority. ${ }^{236}$ Like elsewhere in early modern Europe, violence in Bologna was above all a 'spectacle of the streets.'237 Comprising streets, alleyways, squares, street markets and the exterior of public buildings, this space was by no means less important to women than to men. In proportional terms it was even slightly more prominent among women's reported violent offences (54 per cent) than among men's (47 per cent). The reasons that caused blood to boil on the streets were manifold and ranged from disputes over such issues as property and debts or presumed thieving, the mishandling of shared resources (such as the neighbourhood well), spontaneous social altercations and work-related arguments.

The case against a female market vendor nicknamed La sbirazza demonstrates that the defence of economic interests was not reserved for men. On 6 August 1755 married market vendor Barbara Romare had herself medicated by a surgeon at Bologna's Ospedale di Santa Maria della Morte located near to the city's Piazza Maggiore, for a forehead contusion and various facial abrasions. ${ }^{238}$ They were caused by another vendor - La sbirazza - who had pulled her by the hair and dragged her across the piazza while scratching her face with her nails for selling similar wares nearby her stall for too cheap a price. Although these market fights do not carry much quantitative weight among the criminal court records, this kind of violence typifies women's socioeconomic interwovenness in and importance to the urban economy. As economic actors, whether working in the public market place or at home, women did not shy away from defending their economic interests.

Both male and female fighters thus above all settled their violent quarrels in public, but they did not always choose the same location within the urban space. A closer reading of the descriptions of street locations hints at a significant difference between men's and women's use of 'liminal spaces.' Bologna's criminal court proceedings suggest that a lot of women's conflicts occurred not just anywhere in the street, but rather on the doorsteps of their homes, on the threshold, as has also been noted by Christopher Corley for early modern Dijon. ${ }^{239}$ Indeed, it is noteworthy that in 41 per cent of the cases (i.e. a notable two-thirds of the 'street' category) women declared being just outside their

\footnotetext{
236 Howard, 'Crime, communities and authority,' 76.

237 J. Eibach, Frankfurter Verhöre: Städtische Lebenswelten und Kriminalität im 18. Jahrhundert (Paderborn: Ferdinand Schöningh, 2003) 222; Vasta, 'Per una topografia della violenza femminile,' 69; Farge, 'Les théâtres de la violence,' 989-992.

238 ASво, Torrone, 8171-2, fasc. 31: "[...] quale venuta meco a contesa a motive della nostra uniforme professione, pretendo essa dassi le mie a troppo vile prezzo [...]."

Corley, 'On the threshold,' 149.
} 
homes when the violence erupted: when entering or leaving their house, when using the shared spaces in the apartment complexes, while standing in the doorway, leaning against the window and sitting on the doorsteps under the city's portico. The role of these types of locations as descriptive markers in male plaintiff's reports was more limited: 12 per cent in total and 27 per cent of the street category. 240

The following case of two quarrelling neighbours in 1706 is therefore in many ways typical of women's everyday violence committed in early modern Bologna. On 30 March Anna Cattarina Gaspari made her way to one of the criminal court's notaries to denounce her neighbour Teresa following a longstanding conflict between the two. Up until then, Anna Cattarina had been insulted daily by Teresa, who on numerous instances called her an adulterous whore even though she, as she asserts, was in fact a donna da bene - a respectable woman. ${ }^{241}$ On this day, matters escalated into physical violence after Teresa had become vexed by Anna Cattarina's dog walking through her vegetable garden. Upon their encounter just outside their houses, Teresa pelted Anna Cattarina with stones, which did not cause her significant harm because she evaded them and fled the scene.

Violence erupted in places where men and women interacted on a daily basis and the criminal court records suggest that the immediate neighbourhood bore great importance for women - greater than for men. Indeed, it is known that the microcosm of neighbourhood relations functioned as a dense social fabric of interdependencies and reciprocal social control. Most middle or lower class inhabitants of Bologna could not afford to rent or buy their own house and instead lived in apartment complexes with shared courtyards, passageways and entrances to the street. Avoiding those neighbours one was at odds with may have been difficult in these shared spaces, but even the houses themselves offered little privacy since many people merely rented a room within a house. As in other early modern towns, the close proximity to one another and sharing of resources formed an understandable source of conflict and animosity in Bologna. This contextualised the vast array of neighbourly conflicts that made up the bulk of women's violence before the Torrone, motivated by anything from accusations of theft $\mathrm{ft}^{242}$ and taking offence to a another woman presumed flirting with one's husband, ${ }^{243}$ to smaller lingering annoyances ${ }^{244}$,

240 The meaning of this difference in the description of spaces in relationship to violence will be treated in the next paragraph.

241 ASBo, Torrone, 7608-1, fol. 210-211.

242 ASBo, Torrone, 8171-1, fol. 117, 147, 177.

243 АSво, Torrone, 8171-1, fol. 64 .

244 АSво, Torrone, 8179-2, fasicolo 2. 
gossip 245 as well as competition over shared resources and space. The aforementioned wrecking of Teresa's vegetable garden is but one of the many examples of neighbourly petty violence captured in the Torrone's court records in which women acted as protagonists.

The significance of the neighbourhood for women's violence is also distinguished for many other early modern towns in Italy, France, Germany, Holland, and England. ${ }^{246}$ While different source types and administrative traditions render direct comparisons difficult, some 30 per cent of the violent women that came before Rotterdam's lower court had taken place in the neighbourhood, on the sidewalks and streets near their houses. ${ }^{247}$ Similarities in the gendered geography of violence in various early modern towns are suggestive of the existence of a broader, shared pattern relating to women's use of the urban space. While dominant gender norms did not in practice enclose most women inside religious or domestic walls, be it in Catholic or in Protestant regions, they may have meant that that the lives of women, more so than those of men, unfolded mainly in the their neighbourhood streets. The everyday quarrels, brawls and scuffles that found their way into the criminal court records reflect these characteristics.

A comparison of violent offences before the Torrone and Rotterdam's lower criminal court during the first half of the eighteenth century reveals both important overarching similarities and indications of differences. ${ }^{248}$ Similarities between regions and genders were above all found in the profile of the offenders: women were by no means passive accomplices but, like men, mostly acted alone and on their own behalf in their violence against other city dwellers in the public urban space. Importantly, however, Rotterdam's female fighters made up a larger proportion of offenders than in Bologna, and it is hypothesised that the locations of women's fights may help explain this discrepancy. While the geographies of violence were very similar for men and women in Rotterdam, the Bolognese records reveal more distinctly gendered patterns. For male Bolognese fighters, the locations very much resembled those of Rotterdam: 84 per cent of the men accused of committing physical violence before the Bolognese criminal court had fought their quarrels out in the street, on markets and squares, near public buildings, in taverns, and at work-related

\footnotetext{
245 ASво, Torrone, 8171-1, fol. 36

246 L. Nussdorfer, 'The politics of space in early modern Rome,' Memoirs of the American Academy in Rome 42 (1997) 162; Roussel, 'La description des violences féminines,' 78; Eibach, 'Böse Weiber und grobe Kerle,' 679; Van der Heijden, Women and crime, 87; Beattie, 'The criminality of women,' $83,87,102$.

247 Van der Heijden, Women and crime, 87, 92.

248 Van der Heijden and Muurling, 'Violence and gender,' 695-716.
} 
locations - just like their violent male and female counterparts in Rotterdam. The prevalence of houses and their immediate vicinities for Bologna's female fighters set them apart. They furthermore much more rarely operated in taverns, near public buildings or workshops.

Several factors that may have caused these gender differences in Bologna's geography of violence in Bologna have already been discussed, such as practices related to labour and sociability. Another factor was the built urban environment, in which apartment complexes and their communal facilities, passageways, courtyards and gardens were separated from the street by a large door, and imposed a notoriously intrusive cohabitation that lay at the basis of many quarrels. ${ }^{249}$ This especially affected women, since both their work and social lives were centred in these spaces more so than men's. Lastly, Italian cities' legislation functioned as the normative framework for the gendered geography of violence. Bologna's municipal decree against unescorted mobility targeted presumed prostitutes, but ensured that all women not shepherded by their husbands or male kin after dad were liable to be treated as courtesans by the men in town as well as by the police. The existence of this type of legislation likely meant that authorities did actually expect women to be in the streets, and there is furthermore little evidence of a strict enforcement of these regulations. ${ }^{250}$ Nevertheless, the court records do illustrate that the gendered expectations presented limitations to women: as it stigmatised if not restricted their presence, movement and behaviour in the urban space.

\section{Framing Men's and Women's Violence}

Normative perceptions of how men and women should behave also influenced criminality in a different way. The judicial records reflect both real and fictional differences in how, where and why men's and women's violence was committed. Zemon Davis described how supplicants appealing for mercy in sixteenth-century France constructed tendentious versions of their lives and crimes to persuade the king and courts to issue a pardon for their crimes. Through the example of these so-called 'pardon tales,' she scrutinised the fictional qualities of judicial records, i.e. the "forming, shaping and moulding elements: the crafting of a narrative." ${ }^{251}$ As well as a historical account of past

249 Ibidem, 127-128; Muurling and Pluskota, 'The gendered geography of violence in Bologna,' 159 .

250 Ibidem, 304.

251 Zemon Davis, Fiction in the archives, 3. 
actions or observations, texts of crime should therefore also be viewed as a series of narratives that are packaged in a certain way to augment their probative power, directed at pleasing a certain audience. ${ }^{252}$ An examination of the fictional dimensions of these narratives is particularly relevant for the study of violence since its punishment was decidedly negotiable.

Fictionalisation does not equate to falsity per se, nor does acknowledging that judicial records were subject to moulding and shaping mean that these sources cannot be used to gain an image of actual fights. In his examination of knife fighting in seventeenth- and eighteenth-century Amsterdam, Spierenburg contended that there was no "fiction in the archives here" because of the magistrates' careful inquiries, the interrogation of several witnesses, and the fact that the interrogation protocols regularly contained different versions of the defendants' confessions. ${ }^{253}$ As such, he contrasts the fiction of the archives with "the real story," although he also admitted that the defendants' "strategies certainly played a part." 254 There is little need to oppose these aspects, as they were, according to Zemon Davis and others, two sides of the same coin. Scrutinising prevalent narrative tropes helps both in discerning ideas about appropriate and inappropriate behaviour, as well as in determining the strategies used by plaintiffs and defendants in employing them to their advantage.

The forming, shaping and moulding of details occurred at all levels of the criminal process. Zemon Davis' account of the pardon tales describes the defendants' attempts to convince the judge that they should receive a pardon for their crimes. But not only defendants moulded their narratives. Already in the late 1980s Thomas Kuehn cautioned against a naïve reading of court cases without reference to the formative role of the court in the witness testimony. 255 He argued instead that legal procedure shaped the testimony of witnesses and, consequently, that the filter of legal rules and terms subtly restructured social realities. ${ }^{256}$ In a similar vein Edward Muir and Guido Ruggiero have emphasised that both accusations and investigations tried to force the details of an event in the mould of what was required or perceived to be required to designate a specific action as a crime..$^{257}$

252 For a recent treatment of the narratives in crime texts, see P. Arnade and E. Colwill, 'Crime and testimony: Life narratives, pardon letters and microhistory,' Journal of medieval and early modern studies 47:1 (2017) 147-166.

253 Spierenburg, 'Knife fighting and popular codes of honor,' 106-107.

254 Ibidem.

255 T. Kuehn, 'Reading microhistory: The example of Giovanni and Lusanna,' The journal of modern history 61 (1989) 518.

256 Ibidem, 515, 519.

257 E. Muir and G. Ruggiero, 'Afterword. Crime and the writing of history,' in E. Muir and G. Ruggiero (eds.), History from crime (Baltimore: Johns Hopkins University Press, 1994) 235 . 
A judicial narrative's mould was not only shaped by perceptions of criminality, but was furthermore constructed along lines of gender and class. Notably, Zemon Davis' argues that early moderners, especially the men, could draw upon distinctive understandings intrinsic to their estate. ${ }^{258}$ From the pardon tales she discerned various different 'anger plots,' i.e. the contexts and procedural unfolding of violent escalations, which clustered around the social types of gentleman, artisan and peasant. ${ }^{259}$ While 'peasant tales' often involved either the rivalry of suitors or inheritance, the 'gentleman's tale' revolved around defending his rights as a seigneur and his honour as a gentlemen, while the tales of artisans and tradesmen concern disputes in the realm of work, payment, theft and debt. Although further examination is necessary, it is not difficult to imagine that this typology would also hold for the rest of the criminal court proceedings.

Aside from class, themes and assumptions also clustered distinctly around gender. Ideas about appropriate masculinity and femininity take up an implicit yet fundamentally formative role in the representation of behaviour in the judicial records. For men, court records hint at notions of culturally demanded retributive violence. One good and almost stereotypical illustration of this is the homicide trial against Nicolo Sgariglia, a cavaliere nicknamed Il Sergente, who was prosecuted for the murder of another soldier called Marsilio Tomassini in June $165^{2} .{ }^{260}$ The death of Marsilio, who had wounds on the left side of his hand and arm and was found deceased just outside a tavern, was brought to the attention of the Torrone through a 'secret friend of the court,' who informed the bargello (chief of police). Figuring out who had committed this murder did not prove to be too difficult, as there had been several witnesses to the act though perpetrator Nicolo was nowhere to be found. The witness testimonies speak volumes regarding the motivation behind the fight. Tavern keeper Antonio Santi vividly described how the offender came into his osteria to eat and drink and had an argument with victim Marsilio over a previous altercation with his friend. Marsilio had asked Nicolo why he had bothered his friend, which Nicolo denied doing. Nicolo then asked to speak to Marsilio outside the tavern, saying he would not stand for such accusations, that he was an honourable soldier and demanded 'satisfaction.' Marsilio cursed at Nicolo, calling him a gridone et un ladro (bawler and a thief), to which Nicolo responded by saying he was in fact a galanthuomo (gentleman) and that he was willing to defend this reputation with his sword. He urged Marsilio to retrieve his own sword

\footnotetext{
258 Zemon Davis, Fiction in the archives, 43.

259 Ibidem, 38.

260 AsBo, Torrone, 6620 , fasc. 3 .
} 
from inside, saying that he was a pig if he would not fight him, and waited for him. Once outside, the two men drew their swords and started battling. Marsilio received a deadly blow to the head and Nicolo - in absentia - was convicted and sentenced to the galleys for ten years.

The murder case of Marsilio and Nicolo speaks to the ritualised nature of violence in early modern societies. Although the court records make no explicit mention of it, the circumstances that led to Marsilio's untimely death very much resembled the duels treated extensively in historical literature. It also contains many of the classic ingredients of Zemon Davis' honour-driven 'gentleman's tales.' The dispute started in a tavern, took place between gentlemen who fought each other one-on-one with equal weapons after an encroachment upon the honour of one of them and a challenge to fight outdoors to settle the dispute once and for all. Although concepts of honour in relation to violence are usually discussed at the level of the nobility, it has been argued that they were crucial to individuals of all social levels. ${ }^{261}$ According to Spierenburg much of the knife fighting in Amsterdam until the eighteenth century followed distinct rules and norms and represented a plebeian manifestation of male codes of honour. ${ }^{262} \mathrm{He}$ therefore called this kind of violence 'popular duels.'

In the Bolognese court records both the 'equal' and 'unequal' fights among the lower social strata relate to masculine honour in one way or another. The denunciation against Giovanni Cancella, a tavern boy from Medicina in Bologna's countryside, underlines that violence was considered an accepted and sometimes even demanded response to an encroachment of their honour for men of all social stripes. On 10 December 1652, the Bolognese stable master Piero Rovani denounced Giovanni Cancella for having hit him on the head with a pitchfork in the stable where Piero worked. ${ }^{263}$ Piero asserted that Giovanni had probably hit him because he had previously intervened in a quarrel between Giovanni and another worker. When interrogated some ten days later, however, Giovanni himself provided quite a different explanation. After asking Piero for a key to one of the stables, Piero had mocked Giovanni and had called him a blind man and a fucking cuckold (huomo orbo, becco fotuto) in the presence of another colleague. Angered by this belittlement, Giovanni hit Piero on

261 T.V. Cohen, 'The lay liturgy of affront in sixteenth-century Italy', Journal of social history 25:4 (1992) 610.

262 P. Spierenburg, 'Faces of violence. Homicide trends and cultural meanings: Amsterdam, 1431-1816,' Journal of social history 27:4 (1994) 709-711; N. Worden, 'Public brawling, masculinity and honour,' in N. Worden (ed.), Cape town. Between East and West (Hilversum: Verloren, 2012) 197; Spierenburg, 'Knife fighting and popular codes of honor,' 103-127. ASBo, Torrone, 6620, fol. 171-172, 221-225. 
the head with the pitchfork. When asked by the court whether he perceived his actions as a criminal offence, he answered that he did not think so: if Piero had not insulted him, he would not have hurt him either. He had only wounded Piero, he stressed, "for his necessary defence." 264 In this regard, even these supposed unfair fighters appealed to cultural notions of honour and retributive violence to defend their actions. Giovanni portrayed responding violently as inevitable, "because he felt there was no other possibility; he just had to do it."265

Appeals to the interlinked culture of honour and violence were by no means constant over time, nor were they shared among the entire population. That the Bolognese examples were derived from the very first sample period does not seem to have been a coincidence. Amsterdam's deadly, 'honourable' knife fights are believed to have disappeared after around the 1720 s in favour of the violence emanating from conflicts in intimate relationships. ${ }^{266}$ Some scholars have suggested that conceptions of honour changed during the eighteenth century, lessening the need to act in a certain way because of it. ${ }^{267}$ In the Bolognese judicial narratives female fighters, furthermore, never alluded to the necessity to respond violently to an encroachment of their honour. Even though the circumstances and contexts from which violence erupted often comparable to men's, women would or could not invoke the same tropes suitable for and useful to men's judicial narratives.

That the testimonies of women regarding violence did not employ the same topoi or tropes as men's is likely to have had a cultural explanation. The first part of this rationale related - again - to the honour code. Various scholars have remarked that early modern Italian women's engagement in aggressive behaviour was neither expected nor desirable from a cultural perspective. ${ }^{268}$ In a very practical sense there were no customary rules for fighting women, and they could not be formally challenged in honourable fights. In terms of defence, women's anger therefore seemed to have few acceptable uses. According to Zemon Davis' account of sixteenth-century France, for a woman,

264 Ibidem, fol. 223v: “[...] et vedendome cosi strapazzate, me sapito per li mani quell forcale de ferro et per mia diffesa da una sola bastonata al medemo Piero che lo colpi nella testa [...]" and fol. 224r: "[...] non penso d'essere incorso in pena alcuna per havere ferito il sudetto Pier Rovani per mia necessaria diffesa, che se lui et Battistino non mi ingiurivano io non l'haverei tocco, ne dato fastido [...]."

265 As cited for popular duels by Spierenburg, 'Knife fighting and popular codes of honor,' 105. 266 Ibidem, 107, 121.

267 Spierenburg, 'Masculinity, violence, and honor,' 5-7; McMahon, Eibach, and Roth, 'Making sense of violence,' 15-21; E. Hofman, 'Dikwijls bespied. Sociale controle onder buren in het achttiende-eeuwse Kortrijk,' De Leiegouw 55 (2013) 38;

268 Brackett, Criminal justice and crime, 133-134; Spierenburg, 'Knife fighting and popular codes of honor,' 118 . 
only the exceptional scenarios of genuine self-defence, the defence of her children, property, inheritance or religion could be used to justify her anger erupting into violence. ${ }^{269}$

A second part of the explanation lies in literary conventions. It has been remarked that women lacked a dependable set of narrative techniques, as "the general storytelling, Biblical and folktale tradition was ill-supplied with accounts of how women fought."270 This made it difficult for women to appeal to these modes to explain their behaviour. The language of masculine violence permitted the framing of their conflicts in terms of manhood and honour, while women had significantly fewer conventions to draw on. ${ }^{271}$

In their denunciations and testimonies, women therefore employed different narrative strategies from men. There is abundant literature linking women's legal status in Roman law (as the imbecillitas or fragilitas sexus) to leniency in the prosecution and sentencing of women, but there is no consensus on whether or not women actively appealed to their supposed weakness in their defence. Summarising the works of others on various German early modern towns, Eibach suggested that women appearing before the criminal court presented themselves as weak women, whose disposition was disinclined towards violence. ${ }^{272}$ Zemon Davis on the other hand found few of these kinds of references. In her examination of the French sixteenth-century pardon tales, female offenders neither pleaded their imbécillité, nor did they claim irresponsibility due to their husband's presence or directions. ${ }^{273}$ While female offenders in early modern Bologna certainly encountered discretionary gendered paternalism, the court records lack references to their active appeal to notions of weakness or minority.

One of the most noticeable gender-specific narratives for women instead related to their use of space; a narrative formed by plaintiffs rather than defendants. In their denunciations female victims of violence invariably portrayed the street as a thoroughfare rather than a space of sociability. They reported walking to and from certain places during the day and evening, particularly to and from mass, but did not declare congregating with their friends as men often did. Lined with its distinct porticos, court testimonies depict Bolognese streets as places where men gathered socially. Male plaintiffs reported having become the victims of violence while sitting on benches under the

\footnotetext{
269 Zemon Davis, Fiction in the archives, 81, 94-96.

270 Ibidem, 101-102.

271 Walker, Crime, gender and social order, 97; Zemon Davis, Fiction in the archives, 104; Howard, 'Crime, communities and authority,' 85.

272 Eibach, 'Böse Weiber und grobe Kerle,' 672.

273 Zemon Davis, Fiction in the archives, 84.
} 
porticos, while playing cards, watching puppet plays on the piazza, playing games, or drinking in and around the taverns or the city gates throughout the day and evening. With the notable exception of the plaintiffs who were working in the market or in the city's many osterie when they became the subject of violence, the majority of female plaintiffs invariably stated that they were walking to or from home or church. Otherwise, these women declared that they were standing in doorways, leaning on window sills, sitting on the steps and so forth when they were mistreated.

Both the descriptions of being nearby the house as well as justifiable mobility should be viewed from the perspective of gendered tropes of appropriate behaviour. Court testimonies were moulded by a combination of the conventions of law and judicial practice as well as by popular discourse and the personal, micro-political interests of the speakers. ${ }^{274}$ While it is highly unlikely that the women who reported being assaulted strictly used the streets as thoroughfares from and to home, it is nevertheless telling that they chose to frame their use of this space as such. Although it is known that lower- and middleand arguably even upper-class women used the public urban space for a wide range of purposes, women's uncontrolled presence in it was regarded as threatening. ${ }^{275}$ That many Italian cities' criminal bylaws implicitly link women's unrestricted movement through the city to prostitution is illustrative. Women who were violated on the streets appealed - as a litigation strategy - to tropes of women's acceptable presence in the urban space, which did not extend beyond what was necessary, regardless of their actual behaviour. While male defendants referred in their testimonies to violence as a necessary means to defend one's honour, the statements of women remained rather matter-of-fact, commonplace and devoid of such clear appeals. A certain mundaneness of the descriptions of women's violence in court records has also been observed by scholars working on other regions in early modern Europe. ${ }^{276}$ Ideas about appropriate feminine behaviour do rise to the surface through the denunciations, in which female plaintiffs framed their presence and mobility in the urban space in terms that they probably believed strengthened their positions.

274 E.S. Cohen, “Courtesans” and "whores." Words and behavior in Roman streets,' Women's studies 19 (1991) 204.

275 Brackett, 'The Florentine Onestà,' 274.

276 Walker, Crime, gender and social order, 97; Zemon Davis, Fiction in the archives, 101-104. 
The violent tenor of everyday life in early modern Italy is undisputed, yet its special position within Europe has gone largely undiscussed. The Italian criminal court records attest to a pervasive culture of violence that in some ways stands in stark contrast to developments elsewhere in Europe. Not only do these records expose homicide rates much elevated from those found in more northerly parts of Europe, but they also show a clear preoccupation with a broad spectrum of non-fatal violent behaviours. Overall, in Bologna, violence of all sorts made up over three-quarters of the criminal complaints for which an offender was named. These are significantly higher levels than those recorded in northern European cities, even those brought before the lower summary courts. ${ }^{277}$ Scholars have commonly linked the prevalence of violence in premodern Italy to the enduring cultural importance of a distinctly masculine honour culture, in which men frequently clashed over slights to reputation and status. Combined with presumed restrictive gender roles, the ethics of honour meant that it was neither expected nor desirable for women to engage in aggressive acts.

Despite these stringent normative restrictions, violent behaviour was in practice by no means the preserve of men. This chapter demonstrates that this was as much the case in Italy as it was elsewhere in early modern European societies. Although women arguably did not play a substantial role in the lethal violence committed in the city of Bologna, the criminal court records attest to women's ability and audacity in violently confronting their female and male adversaries. When including the more prevalent pettier forms of violence, urban Bolognese women made up about one-fifth of the violent offenders between the mid-seventeenth and mid-eighteenth centuries - a figure not unlike the ones found in other parts of Europe. Rather than relying solely on men for the defence of their reputation and interests - as prescribed by the ethics of honour - many Italian women took matters into their own hands. While women's violent behaviour may not have found much cultural encouragement, it was too common to be viewed as an anomaly.

Women's violence in early modern urban Bologna was distinct from men's in some ways, but also shared many of its characteristics. Importantly, the overwhelming majority of the non-fatal violence that the Torrone dealt with was 'public,' and concerned brawls between members of their own sex during their daily affairs, arming themselves with whatever items came to hand. Rather than pointing to women's 'enclosed' lives, the reported violent interactions of

Gray, 'The regulation of violence in the metropolis,' 83 . 
Bolognese women testify to the full range of women's engagement in social and economic relations in the early modern town. In some ways their experiences were nevertheless undeniably gendered. The criminal court records reveal that women's violence, more so than men's, often erupted in their immediate neighbourhood and involved their direct neighbours, reflecting some gendered socioeconomic realities of everyday life concerning women's labour activities and sociability, legal constraints limiting women's mobility in the urban space, as well as gendered tropes of appropriate behaviours and spaces in the framing of these violent events.

Individuals' recourse to the criminal court has been fundamental in shaping the image of historical violence. After all, the Bolognese authorities had only little interest in prosecuting the bulk of the reported violent acts and instead accommodated and generally favoured peacemaking practices - which were also preferred by many of the plaintiffs. As such, the verbal and physical aggression recorded in the court records must be viewed from the perspective of conflict resolution, in which men and women used the criminal court as leverage in the small politics of their everyday lives. In seventeenth-and eighteenthcentury Bologna, its inhabitants had been exposed to at least hundred years of institutional intrusion. In addition to the widespread culture of violence, both men and women turned to litigation to mediate and settle their personal disputes, to establish personal boundaries and to make individual statements. Italy's early development of judicial and administrative structures had not thwarted its culture of violence and instead, until the judicial reforms of the nineteenth century, saw it go hand in hand with a culture of peacemaking. As we have seen in this chapter, women were active in both. 